\title{
ISO-NAAKKIMA, A CIRCULAR STRUCTURE FILLED WITH NEOPROTEROZOIC SEDIMENTS, PIEKSÄMÄKI, SOUTHEASTERN FINLAND
}

\author{
SEPPO ELO, TAPIO KUIVASAARI, MARTTI LEHTINEN, \\ OLLI SARAPÄÄ and ANNELI UUTELA
}

ELO, SEPPO; KUIVASAARI, TAPIO; LEHTINEN, MARTTI; SARAPÄÄ OLLI and UUTELA, ANNELI 1993. Iso-Naakkima, a circular structure filled with Neoptoterozoic sediments, Pieksämäki, southeastern Finland. Bull. Geol. Soc. Finland 65, Part 1, 3-30.

A circular Bouguer gravity anomaly with a minimum of $-4.0 \mathrm{mGal}$ and halfamplitude width of $2 \mathrm{~km}$ was recognized at Lake Iso-Naakkima $\left(62^{\circ} 11^{\prime} \mathrm{N}\right.$, $27^{\circ} 09^{\prime} E$ ), southeastern Finland. The gravity low is associated with subdued aeromagnetic signature and notable airborne and ground electromagnetic anomalies that indicate low bedrock resistivity.

The drilling record beneath the recent (Quaternary) glacial sediments, $25-40 \mathrm{~m}$ thick, reveals a $100 \mathrm{~m}$ thick sequence of unmetamorphosed shale, siltstone, quartz sandstone, kaolinitic clay and conglomeratic sandstone that rest on a weathered mica gneiss basement. The upward fining sequence is characterized by red colour, high kaolinite content, and tilted, distorted and brecciated beds. According to the geophysical modelling the diameter of the whole basin is $3 \mathrm{~km}$ and that of the sedimentary rocks $2 \mathrm{~km}$, and the depth is $160 \mathrm{~m}$.

Shock lamellas in quartz clasts of the basal conglomeratic sandstone, almost omnipresent kink banding in micas of the rocks beneath the basin floor and the occurrence of polymictic dike breccia in the underlying mica gneiss suggest shock metamorphism. It was concluded that the basin originated by a meteorite impact. However, the impact-generated rocks were subsequently eroded before the sedimentation and only minor marks of shock metamorphism were preserved.

Lateritic weathering took place prior to deposition of the sediments. Quartz sandstone and siltstone are interpreted as fluvial deposits and the thinly laminated shales as transgressive lacustrine or lagoonal deposits. The microfossil assemblage in the shale includes sphaeromorphs of acritarchs from Late Riphean (Neoproterozoic).

Postdepositional subsidence of the Iso-Naakkima basin, shown by tilted sediments, preserved the sequence from further erosion.

Key words: Bouguer anomaly, aeromagnetic anomaly, electromagnetic anomaly, sedimentary rocks, sandstone, shale, clay, kaolinite, acritarchs, shock metamorphism, meteorite impact crater, Neoproterozoic, Riphean, Iso-Naakkima, Pieksämäki, Finland.

Seppo Elo and Olli Sarapää: Geological Survey of Finland, SF-02150 Espoo, Finland.

Tapio Kuivasaari: Geological Survey of Finland, P.O. Box 1237, SF-70701 Finland.

Martti Lehtinen and Anneli Uutela: Geological Museum, P.O. Box 11 (Snellmaninkatu 3), SF-00014 University of Helsinki, Finland. 


\section{INTRODUCTION}

During the regional gravity mapping programme carried out by the Geological Survey of Finland (GSF) in 1989 an almost circular Bouguer anomaly minimum of $-4.0 \mathrm{mGal}$ was recognized at the northeastern end of Lake Iso-Naakkima, ten kilometers south of the town of Pieksämäki, southeastern Finland (Fig. 1). There is neither indication of this circular structure on topographic

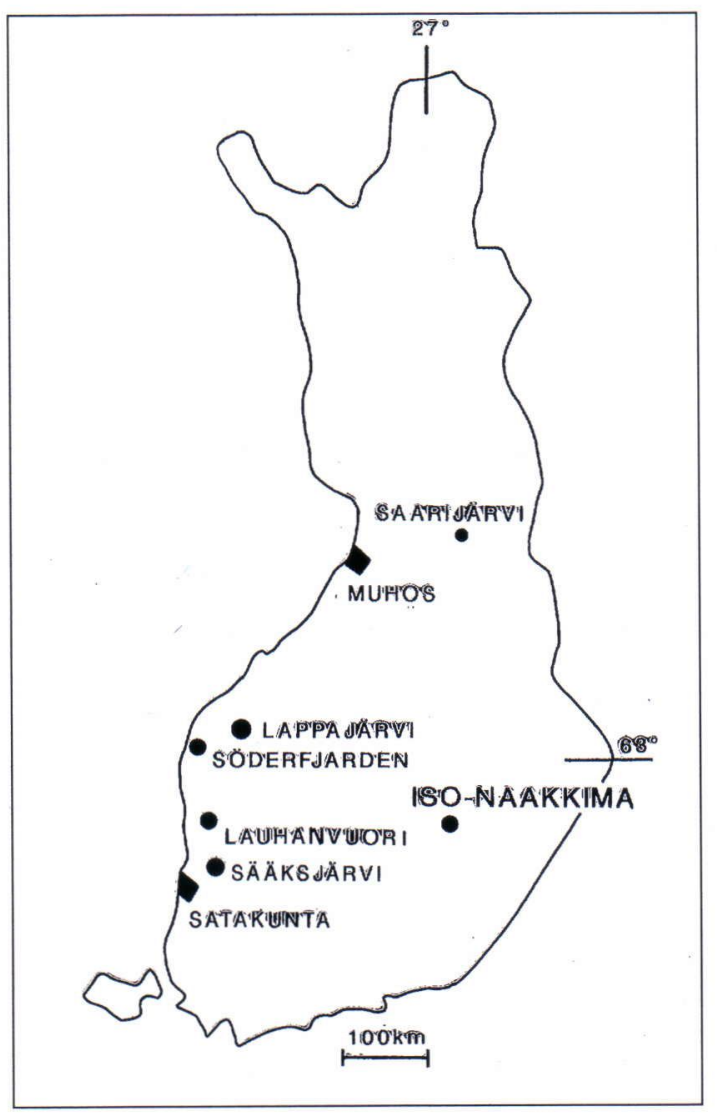

Fig. 1. Location of site Iso-Naakkima and its relation to the Riphean and Vendian sedimentary rocks and possible impact structures in Finland.

maps nor satellite images.

The negative gravity anomaly arose interest as a possible indication of a kaolin deposit. However, after more detailed geophysical measurements and interpretations, a sediment-filled basin initially originating from a meteorite impact was also regarded as a possible explanation for the negative gravity anomaly.

Since there are no bedrock outcrops in the gravity minimun area four holes were drilled by the GSF in the area. Beneath a Quaternary cover, 25 m - 40 m thick, a sequence of unmetamorphosed sedimentary rocks was discovered resting on weathered bedrock of Paleoproterozoic mica gneiss. Due to drilling difficulties in soft sediments, only one hole, drilled near the centre of the gravity minimum, penetrated the sedimentary rock sequence.

In this paper, we describe the Iso-Naakkima sedimentary rock sequence on the basis of drilling and geophysical data. The sedimentary rocks, their microfossils and shock-metamorphic features are also described. The origin of the Iso-Naakkima sedimentary basin is discussed.

In the present study Seppo Elo was responsible for the geophysical investigations and Tapio Kuivasaari and Olli Sarapää for the geological description and interpretation of the sequence. Martti Lehtinen examined the features related to shock metamorphism and Anneli Uutela studied the microfossils.

\section{GENERAL GEOLOGICAL SETTING}

Topography around Lake Iso-Naakkima is rather flat (111 m - $125 \mathrm{~m}$ a.s.l.) with undulating long and narrow moraine ridges or drumlins that trend NWSE. The same NW-SE trend can also be seen in a chain of lakes, tens of kilometers long, including Lake Iso-Naakkima in the area. The bedrock in the vicinity of Lake Iso-Naakkima is covered with Quaternary glaciogenic sediments and therefore the nearest bedrock outcrops are more than three kilometers from the centre of the gravity minimum.

The dominant rock in the study area is mica gneiss with occasional amphibolite intercalations and granitic veins (Vorma 1971). These supracrustal rocks belong to the Svecokarelidic Savo schist belt which underwent magmatism and folding between 
1930 - 1850 Ma (Vaasjoki and Sakko 1988).

The Iso-Naakkima structure is located at the southwestern side of the tectono-metamorphic Raahe - Ladoga zone. The zone is manifested by multistaged fault and fracture systems which occur in the NW - SE-oriented framework running across the country.

Remnants of ancient weathered crust have escaped erosion in the area $8 \mathrm{~km}-30 \mathrm{~km} \mathrm{SE}$ of the Iso-Naakkima structure. Here the GSF has found in-situ type kaolin deposits. In some of these deposits the kaolinization locally reaches a depth of $100 \mathrm{~m}$.

\section{GEOPHYSICAL INVESTIGATIONS}

The Iso-Naakkima structure was first recognized from the regional gravity maps (Elo 1989). The sharp circular Bouguer anomaly (B.A.) minimum looked extraordinary on the colour and grey scale maps of B.A., 2nd vertical derivate of B.A., and horizontal gradient of B.A. The amplitude of the B.A. minimum was about $-4 \mathrm{mGal}$, and its half amplitude width $c a .2 \mathrm{~km}$. The regional gravity data are presented here as a B.A. and so is its 2 nd vertical derivative map (Fig. 2) to indicate the striking anomaly pattern.

The Bouguer anomaly minimum could be associated with the following features on the aerogeophysical maps. It can be seen on aeromagnetic maps (Fig. 3) that magnetic anomalies are subdued in the area of the gravity minimum. Variable area representations (Fig. 4) of aeroelectromagnetic (AEM) data show distinct anomalies with in-phase/quadrature ratios close to one indicating moderately conducting material in the uppermost $100 \mathrm{~m}$ of the structure.

This kind of combination of geophysical anomalies is typical of a class of simple meteorite craters in glaciated Precambrian terraines (Lake Sääksjärvi structure, Fig. 1.; Elo et al. 1992) or to basins of Mesoproterozoic or unmetamorphosed sedimentary rocks, which may also be meteorite impact sites, in the prevailing Paleoproterozoic and Archean terraine (e.g. Lake Saarijärvi, Elo et al.
1983). In either case, the structure is quite uncommon in Finland.

Since the bedrock is covered by thick overburden the only way to sample the basin was by drilling. Before drilling, two detailed gravity profiles were measured and wide-band electromagnetic soundings were carried out along the same profiles (Fig. 5). A short description of the electromagnetic system is given in Soininen and Jokinen (1991). After drilling, petrophysical properties were measured from some drill core samples (e.g. Table 1), and the geophysical profiles were interpreted anew (Figs. 6 and 7).

The gravity minimum is mainly due to the low density sedimentary rocks and the relatively thick overburden. According to the porosity measurements by Liisa Kivekäs at the petrophysical laboratory of the GSF (see Kivekäs 1993 for description of the method) the porosity of the host rock directly beneath the sedimentary sequence is about $2.9+1.3 \%$, which differs by less than one per cent from the usual porosities of similar Paleoproterozoic metamorphic rocks. Obviously, the altered bedrock surrounding the sedimentary rocks contributes to the gravity low. However, the effect is very small and cannot be unambiguously resolved from the gravity anomaly alone.

According to SAMPO wide-band electromagnetic soundings, the low resistivity layers (30 $50 \mathrm{Wm}$ and $140-150 \mathrm{Wm}$ ) extend to a depth of about 150 metres. The less resistive layer (30 - 50 Wm) occurs at the basal part of the sedimentary basin. Saline groundwater trapped into the bottom part of the structure could well decrease resistivity, but no direct evidence for that was obtained due to the collapse of the lower part of the hole after the drilling.

According to the geophysical interpretations, together with the geological observations as constraints, the Iso-Naakkima structure is centered at latitude $62^{\circ} 11^{\prime} \mathrm{N}$ and longitude $27^{\circ} 09^{\prime} \mathrm{E}$. The diameter and depth of the depression filled with glacial overburden and Neoproterozoic sedimentary rocks are $3.0 \mathrm{~km}$ and $140 \mathrm{~m}-160 \mathrm{~m}$ respectively, and the diameter of the sedimentary fill is about $2.0 \mathrm{~km}$. 


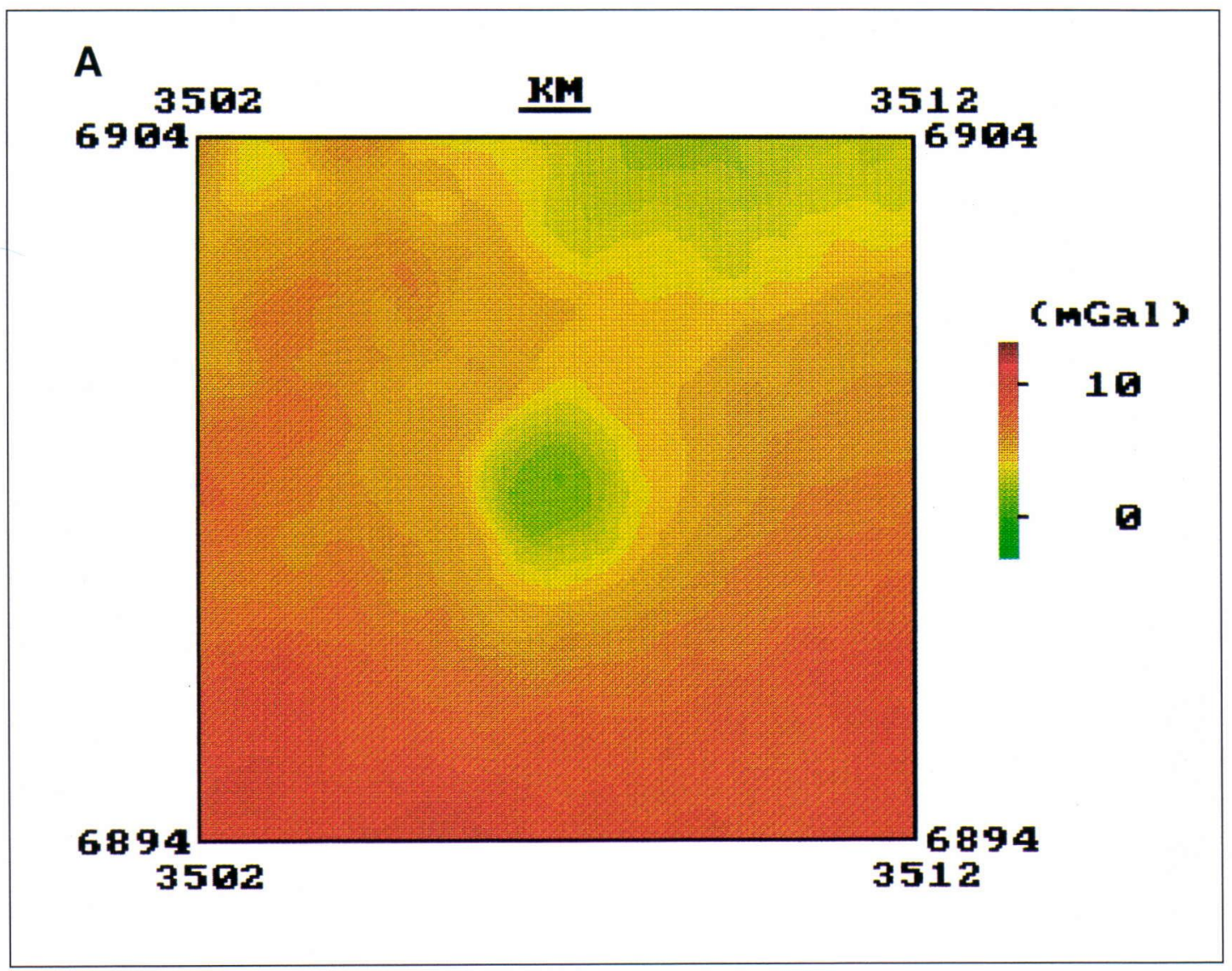

Fig. 2. A. Bouger anomaly map of the Iso-Naakkima area. Density $2670 \mathrm{~kg} / \mathrm{m}^{3}$, no terrain correction. Average station spacing $0.5 \mathrm{~km}$. Map area $10 \mathrm{~km} x$ $10 \mathrm{~km}$.

Fig. 3. A. Total intensity aeromagnetic map. Flight elevation $40 \mathrm{~m}$. Traverse separation $200 \mathrm{~m}$. Flight direction E-W. Map area $10 \mathrm{~km} \times 10 \mathrm{~km}$.

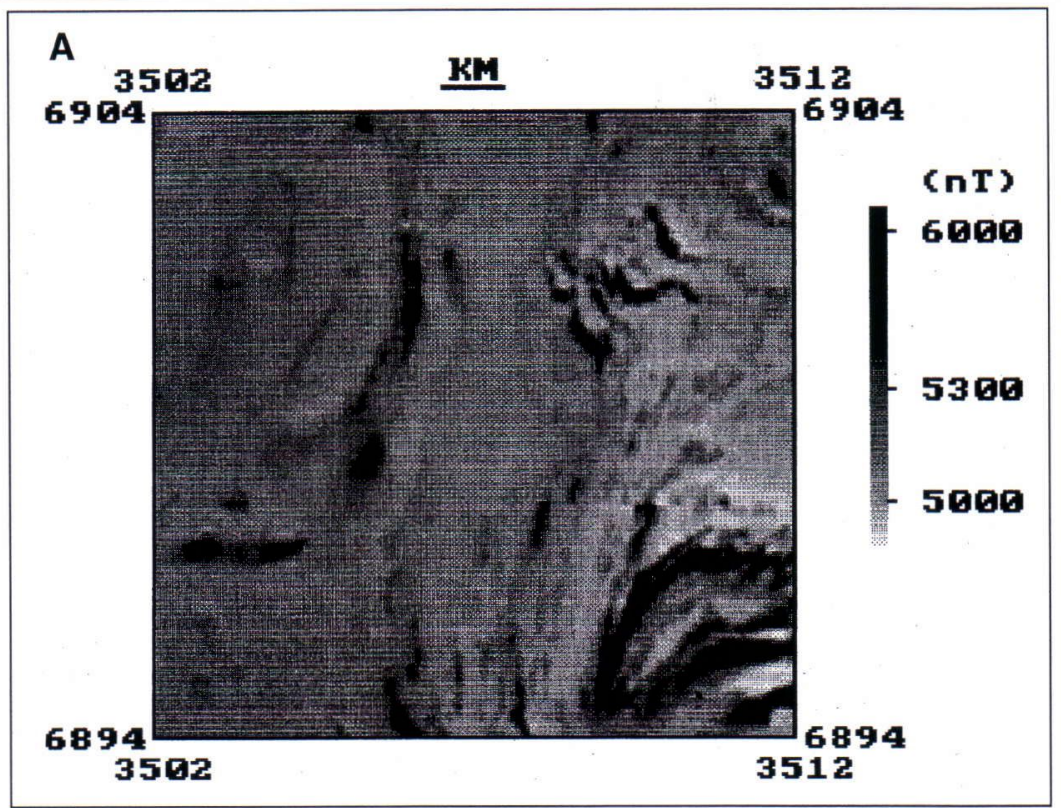


B
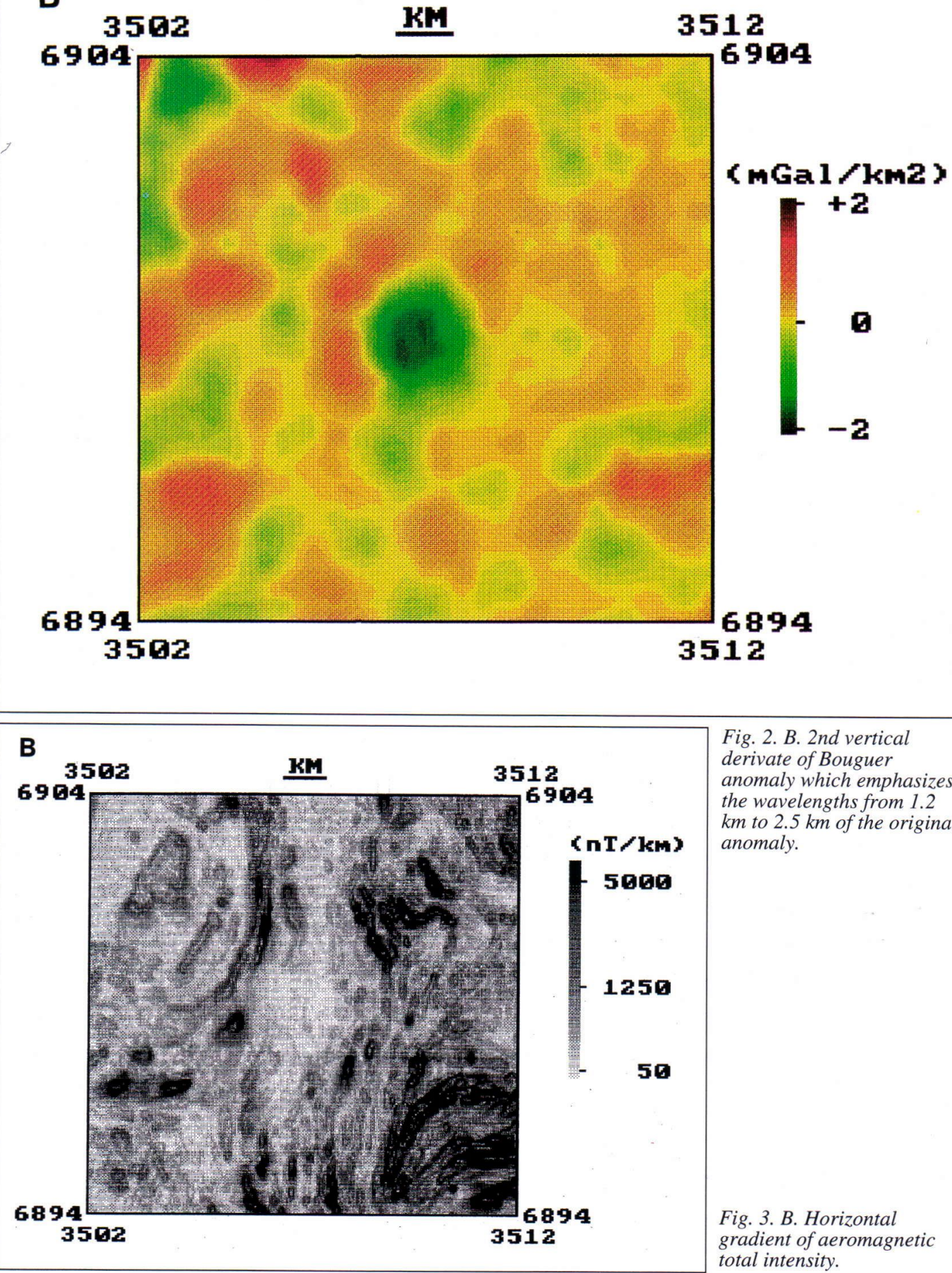

Fig. 2. B. 2nd vertical derivate of Bouguer anomaly which emphasizes the wavelengths from 1.2 $\mathrm{km}$ to $2.5 \mathrm{~km}$ of the original anomaly.

Fig. 3. B. Horizontal gradient of aeromagnetic total intensity. 


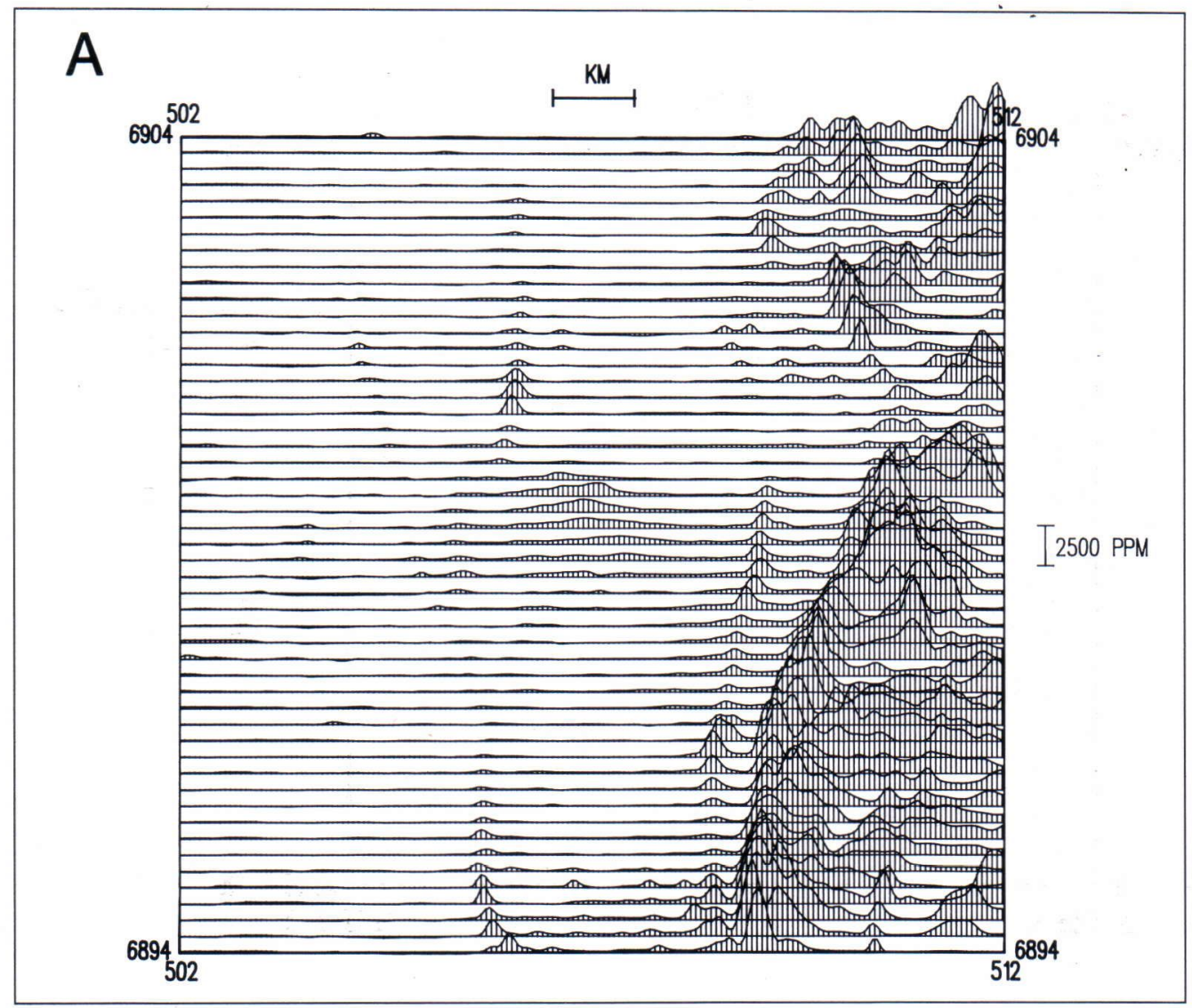

\section{DRILLINGS}

Four holes were drilled in the area of the IsoNaakkima B.A. minimum (Fig. 8). Two of them were done by ordinary diamond drilling, the other two by a diamond drill with wireline-equipment.

The first drillhole ( $\mathrm{DH}$ 382) was placed in the central part of the Iso-Naakkima gravity minimum. The drillhole penetrated a $35 \mathrm{~m}$ thick glacial overburden which was followed by a series of semiconsolidated sedimentary rocks (shale, sandstone and siltstone). The sedimentary rocks were strongly tilted and the dip of bedding was $60^{\circ}$ - $80^{\circ}$. Due to technical difficulties the drilling ceased at the depth of $97.4 \mathrm{~m}$. The base of the sedimentary rock sequence was not reached.

The second drillhole (DH 383) was made in the northern border of the gravity minimum (Fig. 8).

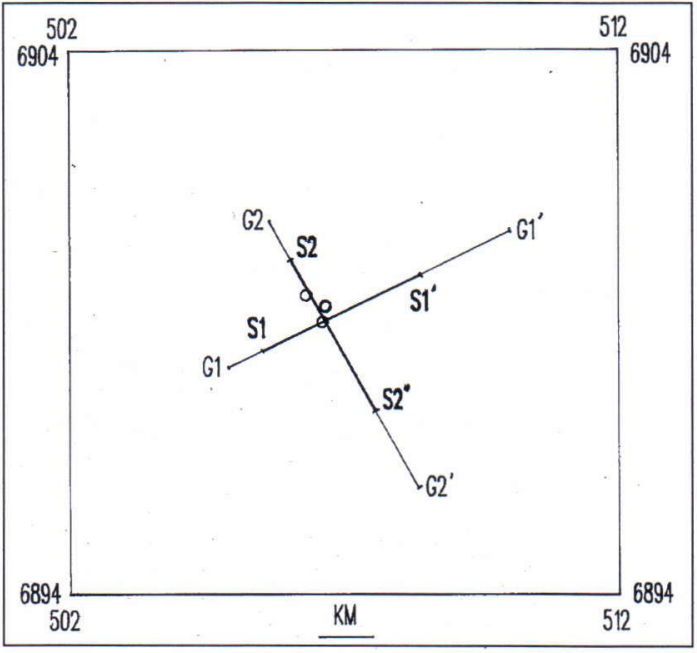

Fig. 5. Locations of detailed gravity profiles $G 1-G 1^{\prime}$ and G2-G2' and SAMPO wide-band electromagnetic sounding profiles $S 1-S 1$ ' and S2-S2'. 


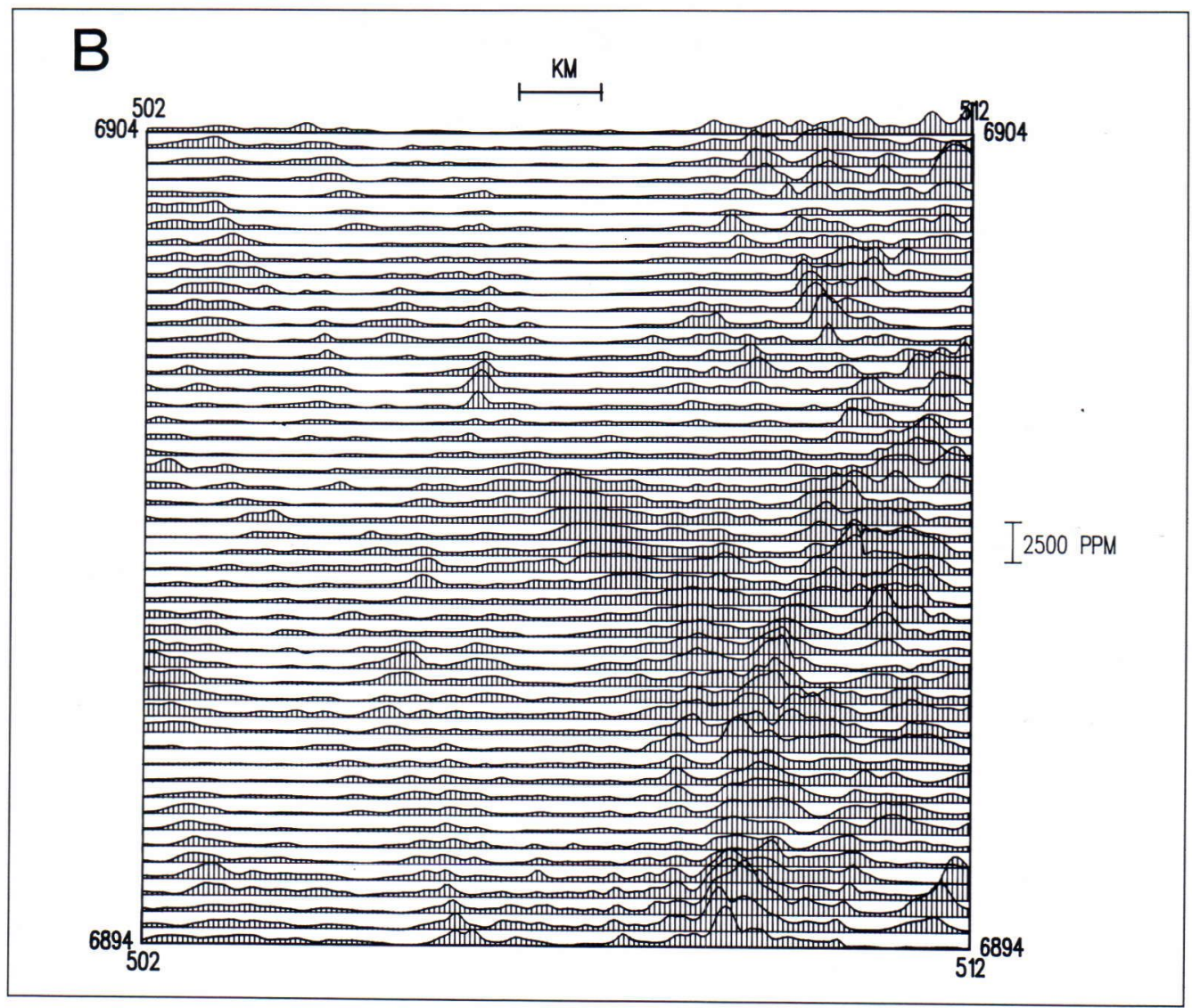

Table 1. Petrophysical properties of the Iso-Naakkima sedimentary rocks.

\begin{tabular}{lllll}
$\begin{array}{l}\text { Drill- } \\
\text { hole } \\
(\#)\end{array}$ & $(\mathrm{m})$ & $\begin{array}{l}\text { Depth } \\
(\mathrm{wet}) \\
\left(\mathrm{kg} / \mathrm{m}^{3}\right)\end{array}$ & $\begin{array}{l}\text { Magnetic } \\
\text { susceptibility } \\
(\mathrm{SI} / 10-6)\end{array}$ & $\begin{array}{l}\text { Remanent mag- } \\
\text { netization } \\
(\mathrm{A} / \mathrm{m} / 10-3)\end{array}$ \\
382 & 41.6 & 2214 & 210 & 40 \\
382 & 70.0 & 2272 & -30 & 40 \\
382 & 90.0 & 2259 & 140 & 20 \\
384 & 78.2 & 2350 & 110 & 10 \\
384 & 102.4 & 2174 & -10 & 10 \\
385 & 111.9 & 2328 & 120 & 20 \\
385 & 116.7 & 2270 & 60 & 20 \\
385 & 120.0 & 2370 & 220 & 10 \\
385 & 121.7 & 2309 & 100 & 10 \\
385 & 135.4 & 2257 & 0 & 10 \\
\hline
\end{tabular}

Fig. 4. Variable area representations of the aeroelectromagnetic data. A. In-phase. B. Quadrature. Vertical coplanar coil configuration. Coil separation $21.36 \mathrm{~m}$. Frequency 3113 Hz. Flight elevation $40 \mathrm{~m}$. Traverse separation $200 \mathrm{~m}$. Flight direction $E-W$. Map area $10 \mathrm{~km} \times 10 \mathrm{~km}$. The range of in-phase values on the map is $6700 \mathrm{ppm}$, and that of quadrature values $3500 \mathrm{ppm}$. 


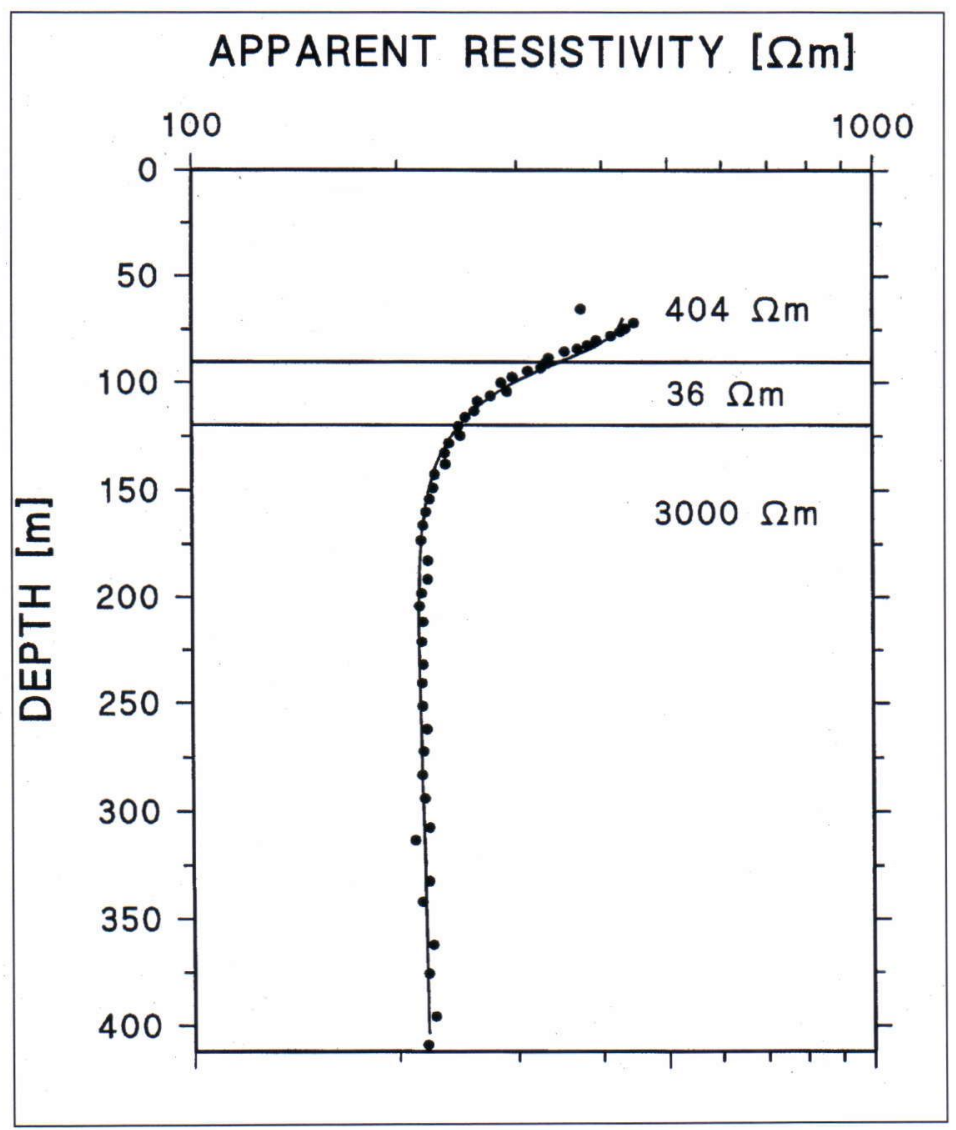

Fig. 6. A layer model interpretation example of SAMPO wide-band electromagnetic soundings at 2.1 $\mathrm{km}$ along the profile $\mathrm{S} 2-\mathrm{S} 2$ '. Dots represent the measured values and the curve the calculated values. Courtesy of $T$. Jokinen and $H$. Soininen.

sequence (siltstone, sandstone, conglomerate) and reached the weathered mica gneiss basement at a depth of $141.5 \mathrm{~m}$. The drilling continued to a depth of $192.4 \mathrm{~m}$. The dip of bedding in the sedimentary rocks was $30^{\circ}$.

\section{ROCK DESCRIPTIONS}

The stratigraphical column of the Iso-Naakkima sequence is shown in Figure 9. It is based on drill cores of DH 384 and DH 385 and the rocks are described starting from the base of the sequence.

\section{Lower Proterozoic basement}

Technical difficulties were again great and the drilling was interrupted at a depth of $54.9 \mathrm{~m}$. At this site the glacial overburden ( $25 \mathrm{~m}$ thick) was followed by siltstone, quartz-sandstone and conglomerate. Core recovery was only $19 \%$.

The third drillhole (DH 384) was placed in the central part of the Iso-Naakkima gravity minimum, ca. $300 \mathrm{~m} \mathrm{NE}$ from DH 382. The dip of the hole was $70^{\circ}$ towards the SW. The thickness of the Quarternary cover was $40 \mathrm{~m}$, and the rest of the sequence contained shale, siltstone and sandstone. The drilling was stopped because of technical reasons at a depth of $102.4 \mathrm{~m}$.

The fourth drillhole (DH 385) was vertical and drilled at the same locality as DH 384. During the first 100 metres only one cutting sample was taken. The drillhole penetrated the sedimentary rock
Mica gneiss (DH 385, 192.4 m - 141.5 m)

The basement of the Iso-Naakkima sedimentary sequence consists of mica gneiss. The core samples show that the rock is veined gneiss, migmatized by granite. The dominant minerals of the mica gneiss are plagioclase, biotite and quartz and in places almandine garnet.

The basal part (192.4 m-150 m) of the drill core consists of fresh but locally fractured mica gneiss. A strongly brecciated rock occurs between 189.85 $\mathrm{m}-189.35 \mathrm{~m}$ and $158.8 \mathrm{~m}-157.8 \mathrm{~m}$. Breccia with fragments of altered mica gneiss, granite and quartz, and dark very fine-grained clasts in a black matrix is interpreted as a dike breccia (Figs. 10 and 20). The upper part of the mica gneiss (150 m - $142.1 \mathrm{~m}$ ) is reddish in colour and partly weathered and brecciated. The weathering grade increases upward, 


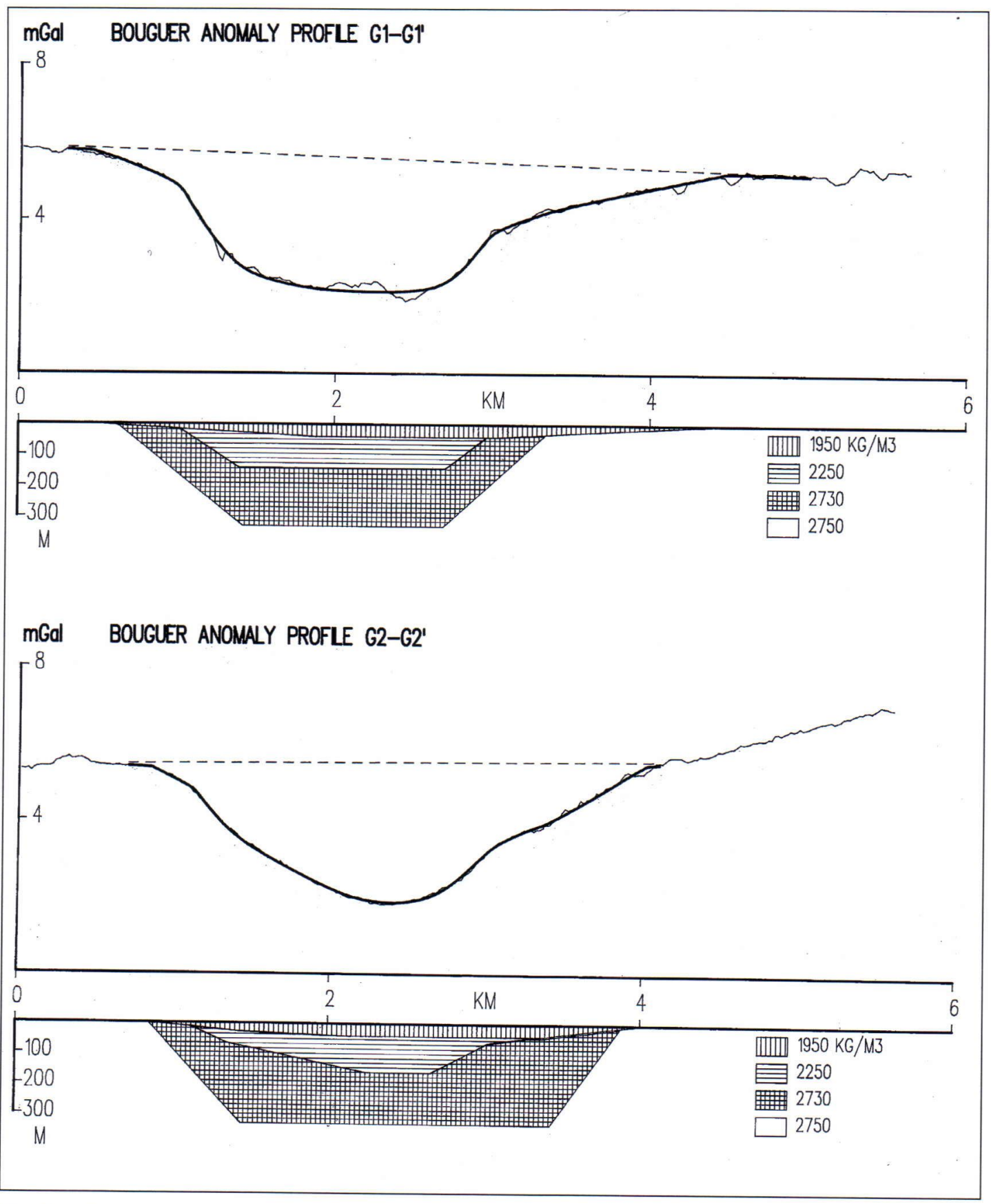

Fig. 7. A. Bouguer anomaly profiles G1-G1' and $G$ '"-G2' (see Fig. 5) were interpreted by means of twodimensional density models. Drill hole data was used as constraint. The thin curve corresponds to the values interpolated from observed data, the thick curve to the calculated anomaly. The density $1950 \mathrm{~kg} / \mathrm{m}^{3} \mathrm{refers}$ to glacial drift, $2250 \mathrm{~kg} / \mathrm{m}^{3}$ sedimentary rocks, $2730 \mathrm{~kg} / \mathrm{m}^{3}$ altered bedrock, and the density $2750 \mathrm{~kg} / \mathrm{m}^{3}$ represents normal bedrock. 


\section{SAMPO WIDE - BAND EM \\ LAYER MODEL INTERPRETATION \\ PROFILE S1-S1}

IN-LINE MEASUREMENTS

COIL SEPARATION $200 \mathrm{~m}$

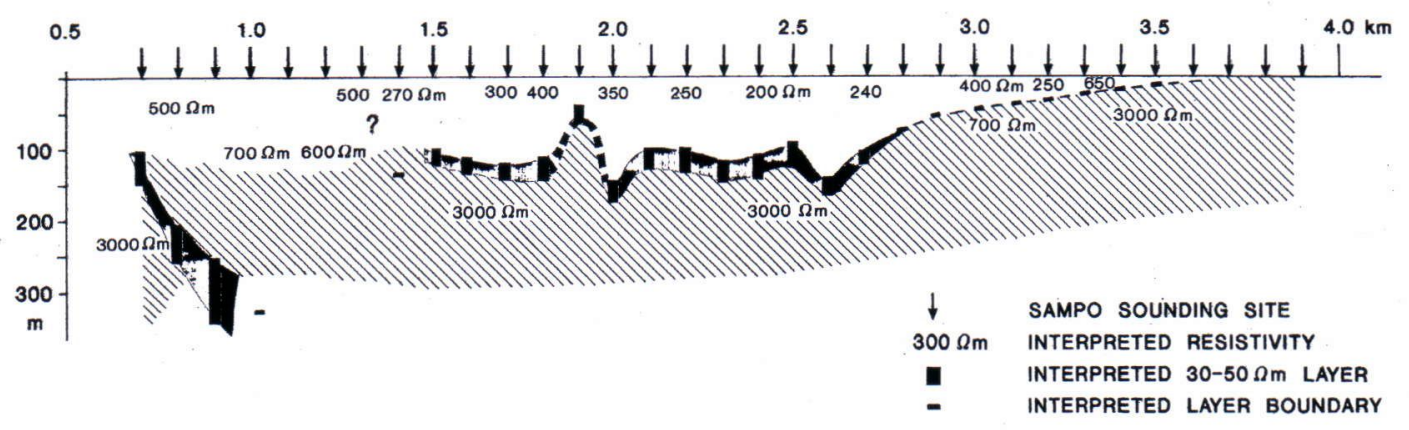

\section{SAMPO WIDE - BAND EM \\ LAYER MODEL INTERPRETATION \\ PROFILE S2 - S2'}

IN-LINE MEASUREMENTS

COIL SEPARATION $200 \mathrm{~m}$.

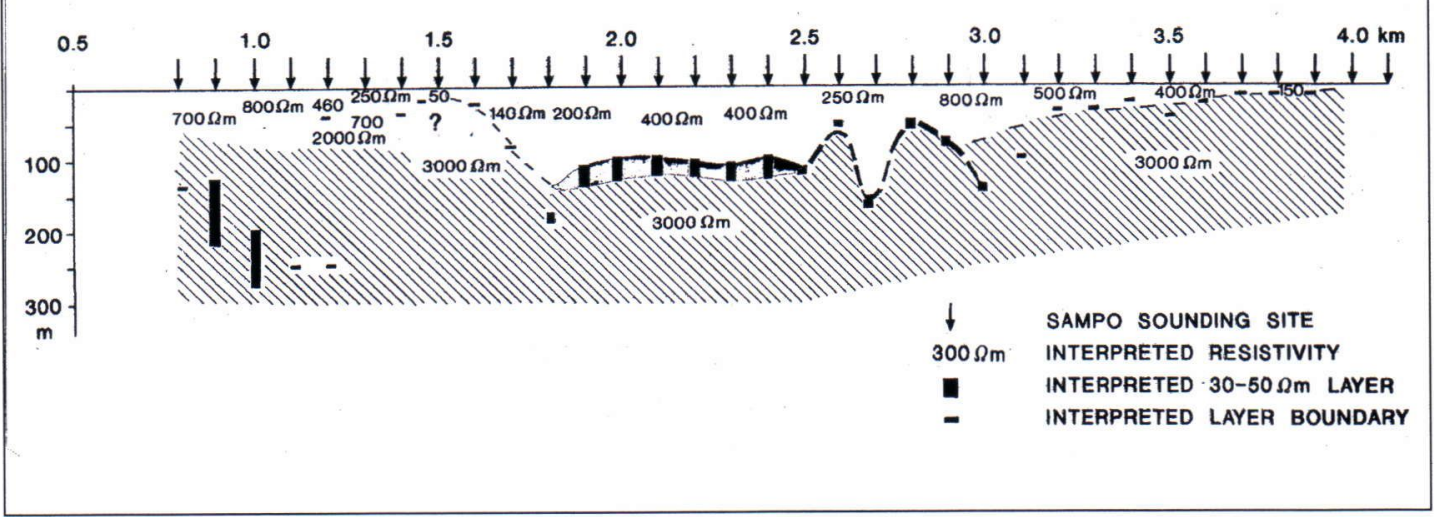

Fig. 7. B. An interpretation of the SAMPO wide-band electromagnetic sounding profiles S1-S1' and S2-S2'(see Fig. 5) by $T$. Jokinen and $H$. Soininen. The most reliable result obtained is the low resistivity layer at the bottom of the sedimentary basin and/or in the altered bedrock near the contact. Low resistivity is probably related to increased porosity of the rocks and high salinity of the groundwater. The separate low resistivity zone observed at the lower part of both profiles is an old structure outside the sedimentary basin. The distances along the $S A M P O$ profiles are counted from the start of the corresponding gravity profiles. Note that the scale of the $S$ profiles differs from that of the $G$ profiles. 


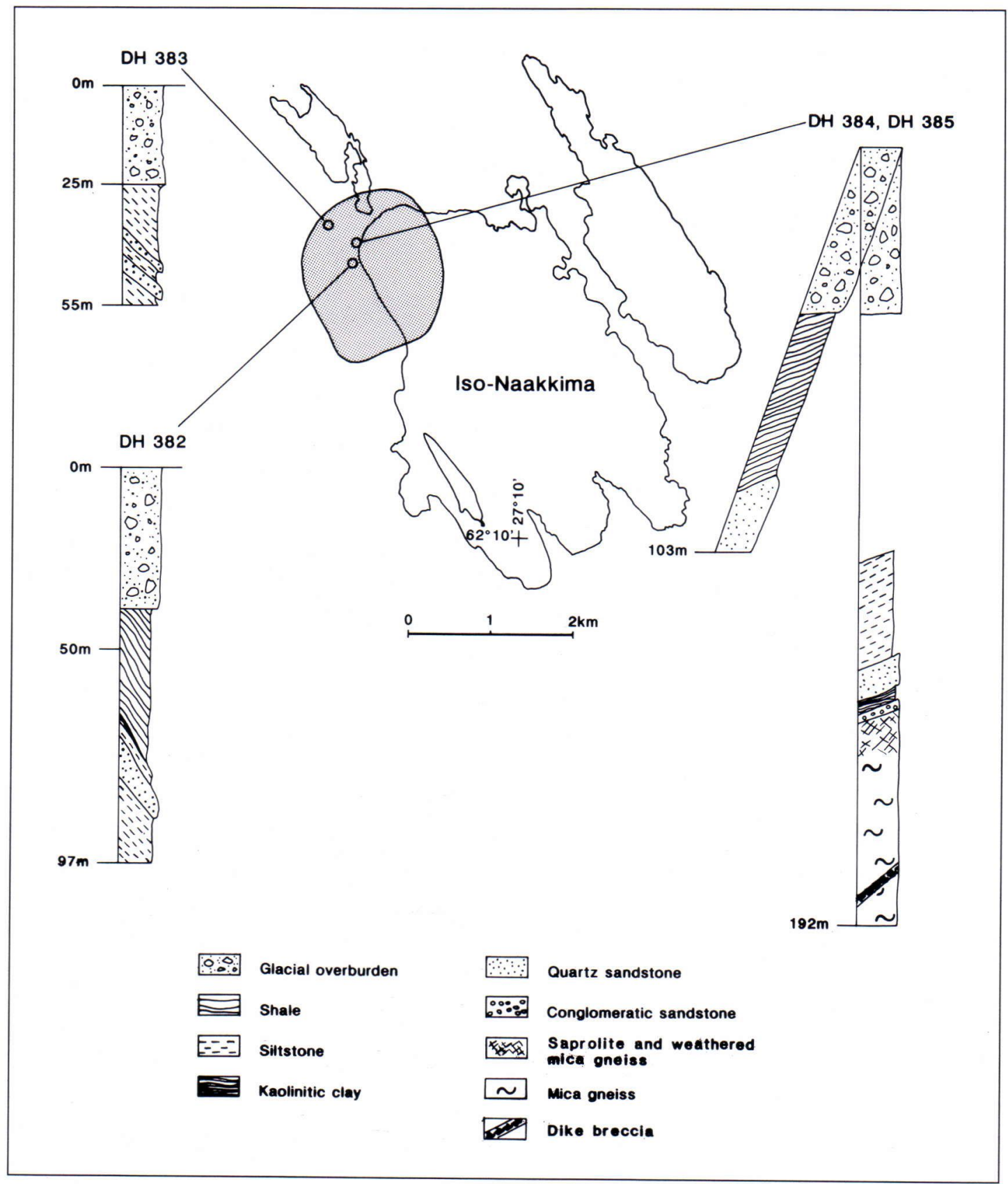

Fig. 8. Outlines of the Iso-Naakkima structure based on the gravity map (shaded area), and locations of the diamond drill holes (DH 382 - DH 385) and drilling profiles. 


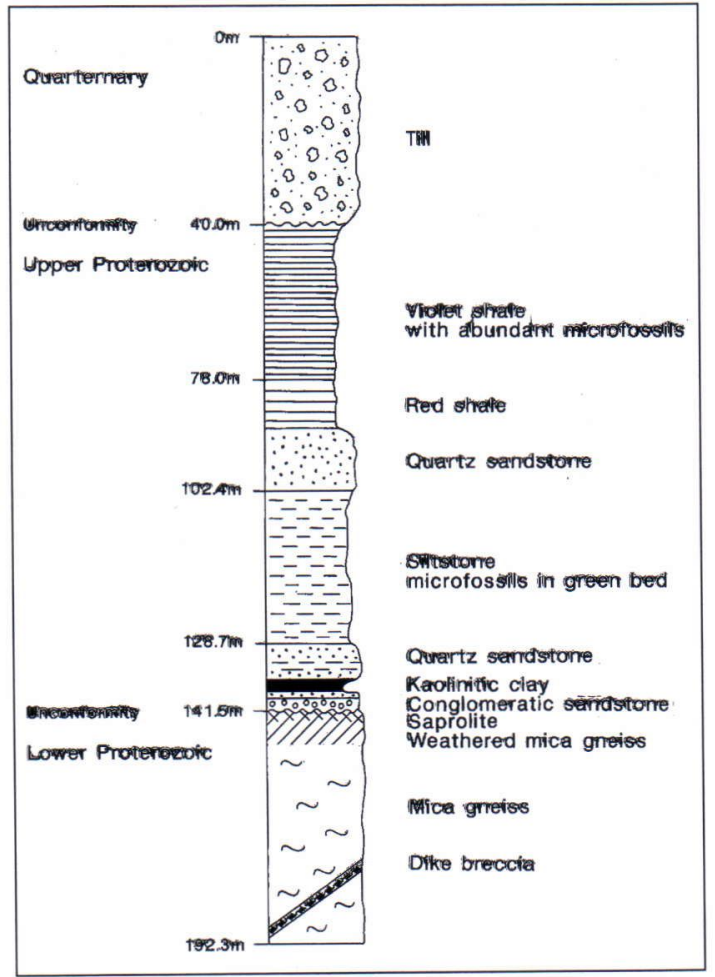

Fig. 9. Stratigraphy of the Iso-Naakkima sedimentary formation based on drill holes DH 384 and DH 385.

and the plagioclase has been partly kaolinized and the biotite altered to smectite and haematite.

The mica gneiss gradually passes upward to reddish brown disintegrated saprolite (142.1 m $141.5 \mathrm{~m})$. However, the primary gneissose structure is still locally preserved. The rock resembles breccia and contains quartz and potassium feldspar (microcline) fragments in a kaolinite, smectite, biotite and haematite matrix.

\section{Upper Proterozoic}

Conglomeratic sandstone (141.5 m - $138.7 \mathrm{~m})$

The conglomeratic sandstone overlies saprolite with a sharp contact (Fig. 9). The reddish grey, concrete-like conglomeratic sandstone is massive but heterogeneous, matrix-supported and poorly sorted (Fig. 11, in the basal part). The amount of matrix is nearly $50 \%$. The clasts are rounded, generally $0.1-10 \mathrm{~mm}$ in diameter. A few bigger pebbles $(\max 10 \mathrm{~cm})$ of weathered mica gneiss are present in the basal part of the unit. Some of the clasts are highly spherical (Fig. 10). Over $90 \%$ of the clasts are quartz. The rest of clasts consist of potassium feldspar (microcline), kaolinitized mica gneiss, altered granite and quartzite. The matrix contains small quartz and feldspar clasts, kaolinite and haematite. The contact with overlying quartzsandstone seems to be sharp, though there is some core loss near the upper contact.

Quartz-sandstone (138.7 m - $138.2 \mathrm{~m})$

The quartz-sandstone is pale grey, indistinctly bedded and moderately sorted (Fig. 11). Its grain size ranges from $0.5 \mathrm{~mm}$ to $2 \mathrm{~mm}$. The rounded

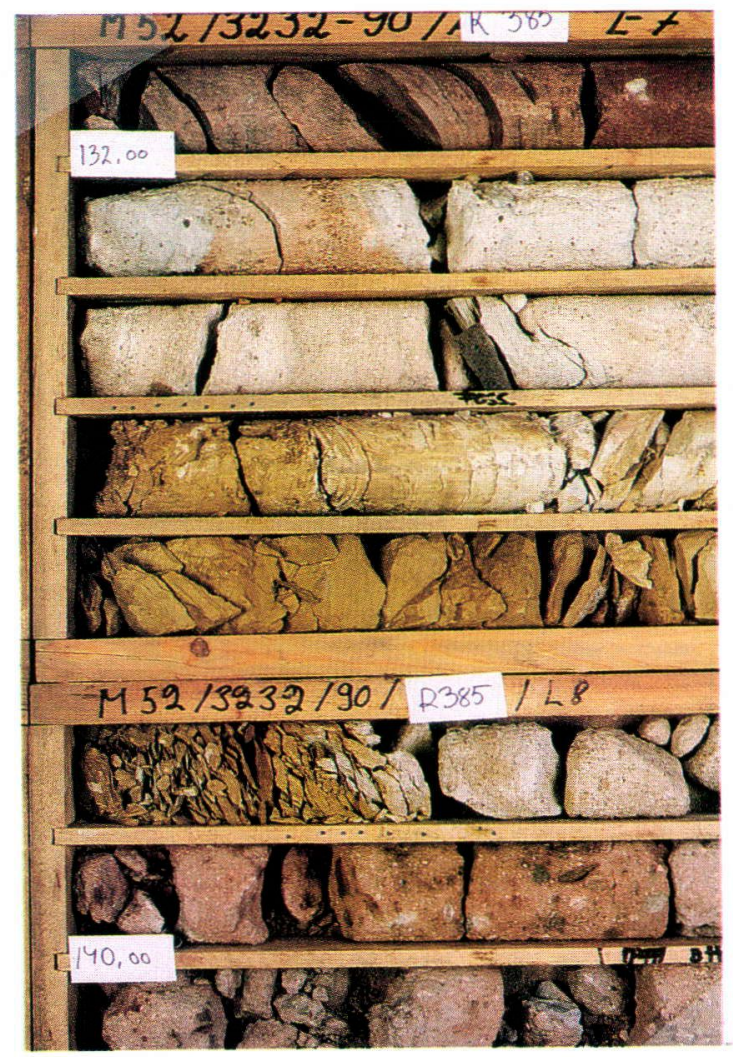

Fig.11. Reddish conglomeratic sandstone, light grey quartz-sandstone, yellow kaolinitic clay, and red siltstone in DH 385, depth 141.5-132.5 m. (Photo by J. Väätäinen). 
quartz clasts are surrounded by a small amount of kaolinite matrix, and a few thin kaolinitic clay layers $(1-3 \mathrm{~cm})$ are also present. The sandstone passes upward into kaolinitic clay.

Kaolinitic clay (138.2 m - 135.6 m)

The kaolinitic clay is yellow, thinly laminated (1 - $2 \mathrm{~mm}$ ) and composed of equal amounts of kaolinite and quartz (Fig. 11, in the middle). The clay contains a few thin $(1-5 \mathrm{~mm})$ sandy interbeds. The upper contact of the unit is sharp.

\section{Quartz-sandstone (135.6 m - $128.7 \mathrm{~m})$}

The quartz-sandstone (Fig. 11, upper part) is pale grey, bedded, and medium to coarse-grained
(0.3 - $2 \mathrm{~mm}$ ) and moderately sorted. The coarse clasts are rounded but clasts are subangular. Clasts mostly consist of quartz but a few potassium feldspar (microcline) clasts are also present. The amount of the kaolinite-quartz matrix is small. The rock contains some grey kaolinitic clay and red silty interlayers $(5-50 \mathrm{~cm})$. The contact with the overlying sandy siltstone is gradual.

Siltstone (128.7 m - $102.4 \mathrm{~m})$

The structures in this bed range from massive to laminated. The massive type is locally mottled with haematite spots or brecciated in small scale in places. The colour is mostly brownish red with some grey massive sandy interbeds $(5-40 \mathrm{~cm}$ thick). Within the laminated parts red and grey
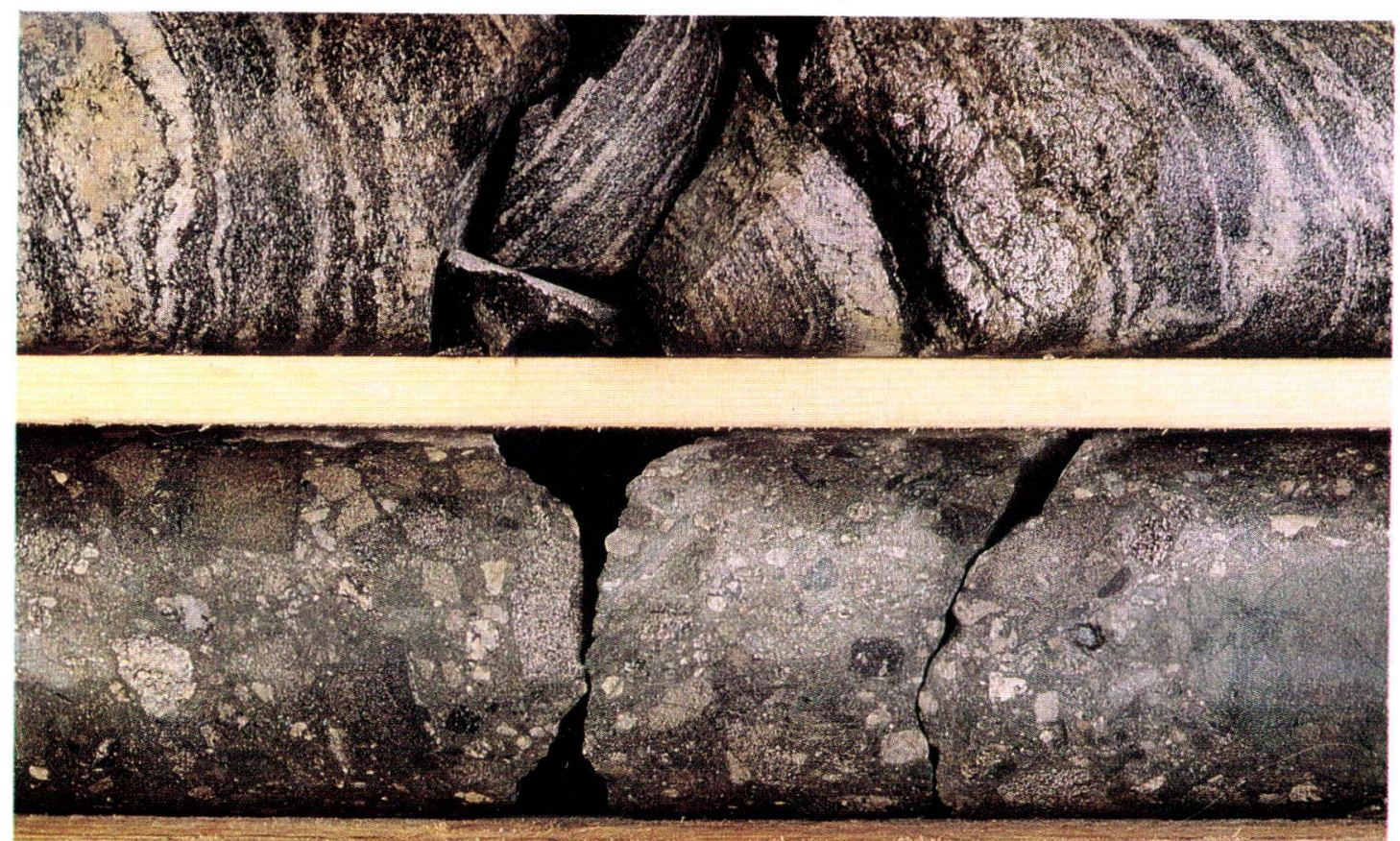

Fig.10. Dike breccia and mica gneiss in DH 385, depth $189.60 \mathrm{~m}$. (Photo by J. Väätäinen). 


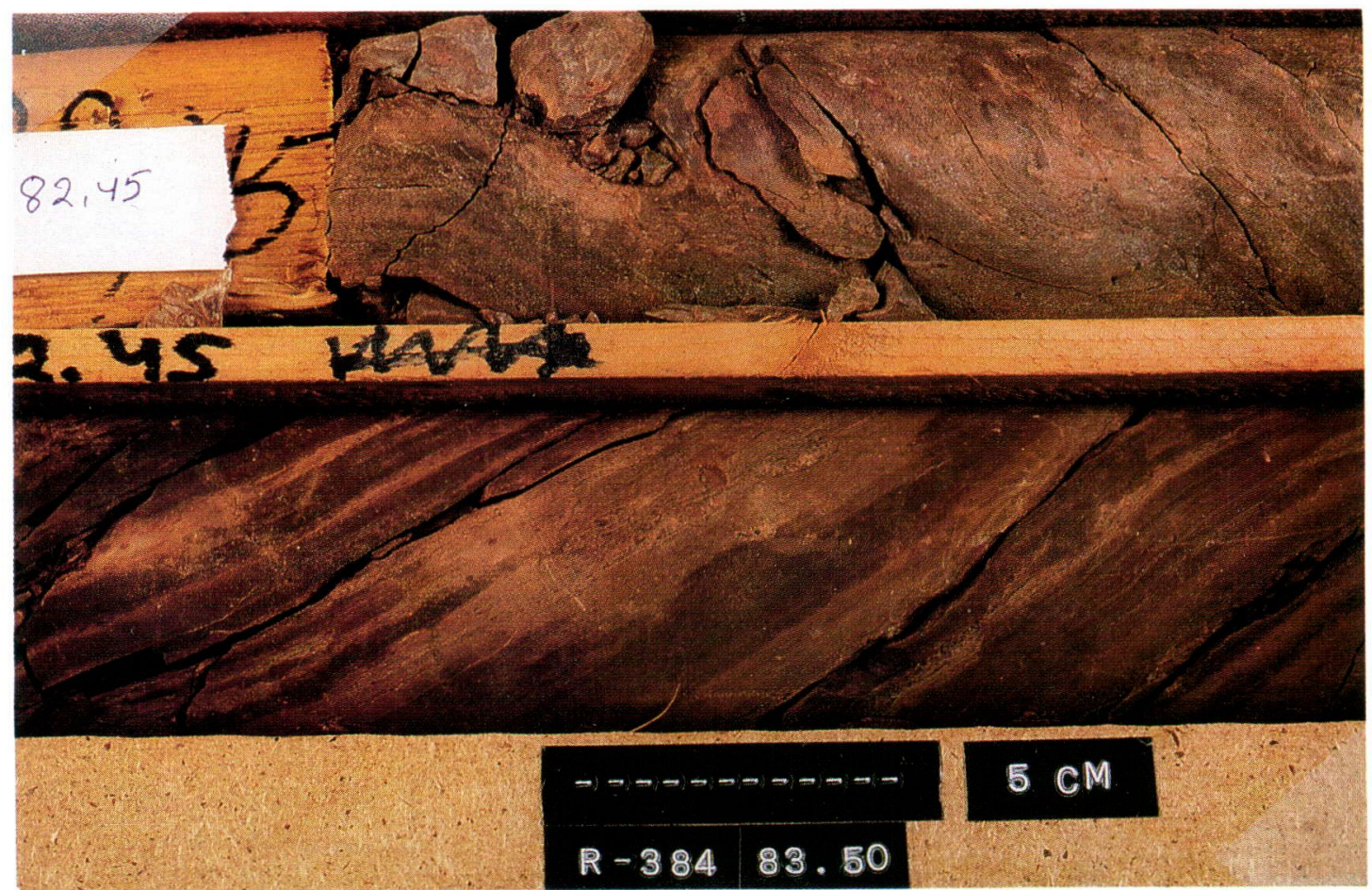

Fig. 12. Red laminated shale. Drill core DH 384, depth 83.50 m. (Photo by J. Väätäinen).

layers alternate. One greenish grey laminated beds occur from $117.4 \mathrm{~m}$ to $114.5 \mathrm{~m}$. Ripple marks were observed in this bed. The siltstone is composed of quartz, potassium feldspar, kaolinite and some muscovite.

\section{Quartz-sandstone (DH 384, 102.8 m - 88.9 m)}

There is a small gap, ca. $10 \mathrm{~m}$, in observations between the two drillholes DH 385 and 384 (see Fig. 8). However, since the drill holes were made so close to each other it is almost certain that the siltstone passes upward into the quartz-sandstone. The quartz-sandstone is pale grey, fine- to coarsegrained, and cross-bedded in small scale. It contains some potassium feldspar (microcline). The sandstone passes first into a metre-thick layer of red siltstone and finally into a red shale.
Red shale $(88.9 \mathrm{~m}-78.0 \mathrm{~m})$

The shale is brownish red, massive and laminated and locally brecciated. It is composed of kaolinite, quartz, potassium feldspar and biotite (Fig. 12).

Violet shale $(78.0 \mathrm{~m}-42.8 \mathrm{~m})$

The violet shale is fissile and thinly laminated. The shale is in places bent and distorted or brecciated. Three hard massive quartz-sandstone interbeds (5 $10 \mathrm{~cm}$ thick) cemented by carbonate occur in the soft shale with sharp but conformable contacts. Two dense sandstone pebbles ( $2 \mathrm{~cm}$ in diameter) embedded in the shale with distorted laminations at a depth of $69.0 \mathrm{~m}$ (Fig. 13). The dominant minerals of the violet shale are quartz, kaolinite, muscovite and potassium feldspar. Thin fissure fillings and 
layers (up to $3 \mathrm{~cm}$ thick) of carbonate are also common in the rock.

The whole Iso-Naakkima sedimentary sequence is characterized by upward fining sedimentary cycles from sand to clay. This trend can be easily seen from the variation of clay content of the sedimentary rocks (Fig. 14).

$\mathrm{X}$-ray diffraction (XRD) results show that kaolinite is the dominant clay mineral (Fig. 15). A small amount of smectite is also occasionally present. On the basis of optical microscopy and

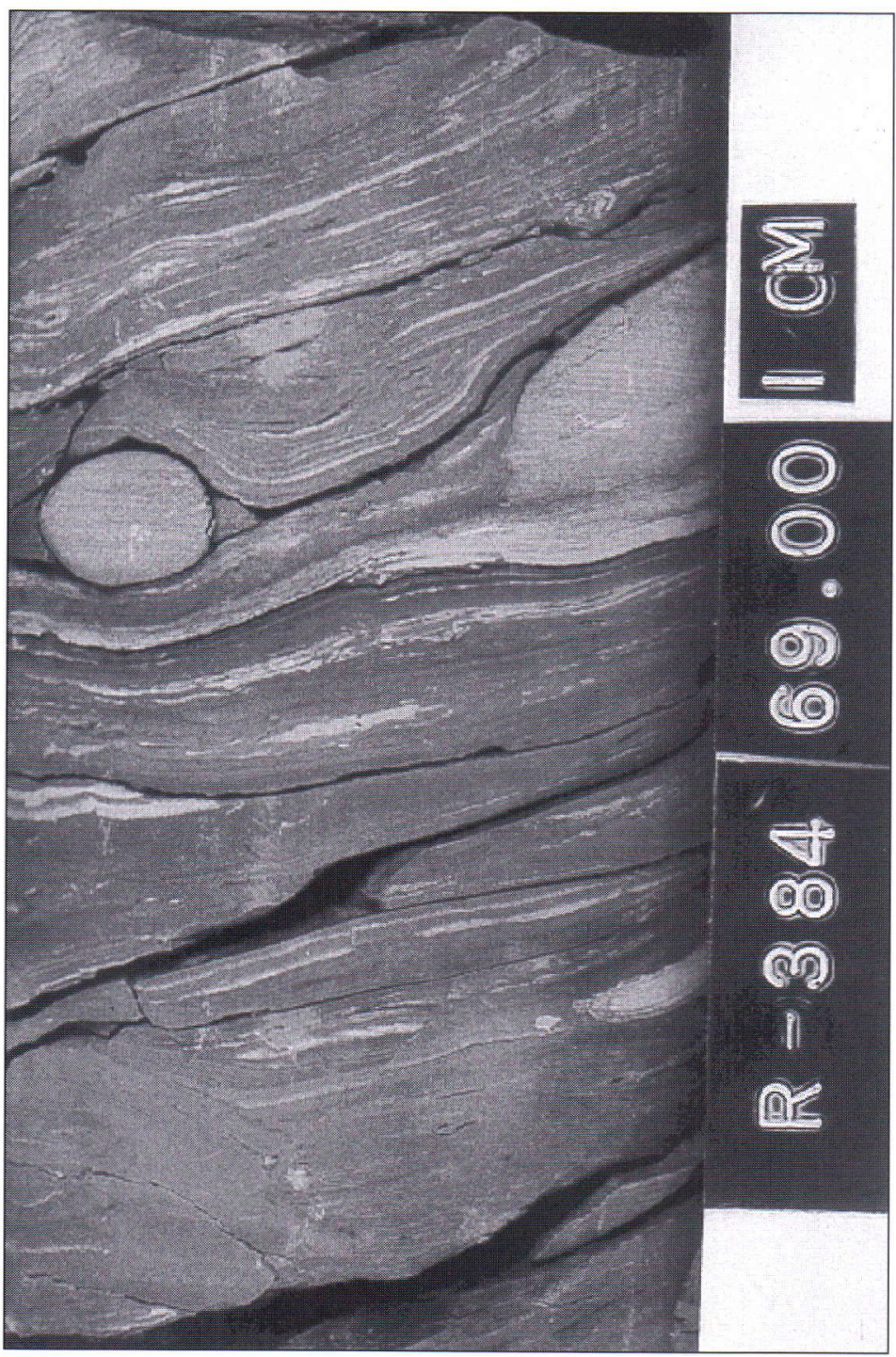

XRD studies, muscovite and biotite are common in both the siltstone and the shale. The content of potassium feldspar (mostly microcline) in the siltstone and the shale is relatively high, $10 \%-30 \%$.

Chemical analyses show that sodium content is very low in all rock types excluding mica gneiss and dike breccia. Magnesium and calcium are low in kaolinitic clay, sandstone and siltstone but rises in shale because the amount of carbonate increases. Kaolinitic clay and shales are rich in aluminium. Chemical analyses also show that quartz sandstones are chemically pure rocks (Table 2). The high kaolinite content and weathering index (CIA) indicate that chemical weathering has been rather intense. The CIA index for the Iso-Naakkima shale is over 80 which is similar to that of residual clays in the work of Nesbitt and Young (1982) and much higher than CIA-index (65) for the average shale in Muhos formation (Simonen and Kouvo 1954, Table 5). The colour of the sedimentary rocks of IsoNaakkima is mostly red, obviously due to the high $\mathrm{Fe}_{2} \mathrm{O}_{3}$ / $\mathrm{FeO}$ ratio.

\section{SEDIMENTARY ENVIRONMENT}

In the East European platform, Riphean sediments were accumulated usually in a continental enviroment; in river valleys, lakes and deltas situated in isolated depressions and

Fig.13. Thinly laminated violet shale, distorted laminations and pebbles resembling dropstones. DH 384, depth $69.00 \mathrm{~m}$. (Photo by J. Väätäinen). 
Table 2. Chemical analyses (XRF method, made at the GSF) of the rocks from the drill cores DH 384 and DH 385.

\begin{tabular}{|c|c|c|c|c|c|c|c|c|c|c|c|c|c|c|c|c|}
\hline \multicolumn{7}{|c|}{ Dh 384} & \multicolumn{10}{|c|}{ Dh 385} \\
\hline Rock & VSh & vSh & VSh & $\mathbf{R S h}$ & RSh & Ss & SIst & Slst & Slst & Slst & Ss & Kaoc & Sapr & WMgn & Mgn & Dbx \\
\hline Depth & 47.4 & 55.8 & 70.5 & 81.5 & 88.4 & 101.9 & 107.6 & 112.8 & 116.4 & 128.0 & 134.8 & 137.6 & 141.6 & 143.4 & 179.2 & 189.4 \\
\hline $\mathrm{SiO}_{2}$ & 56.6 & 53.9 & 54.6 & 52.9 & 55.1 & 94.8 & 77.4 & 71.4 & 80.7 & 74.7 & 90.7 & 50.3 & 64.0 & 61.2 & 54.3 & 50.4 \\
\hline $\mathrm{TiO}_{2}$ & .9 & .8 & 1.0 & 9 & 1.0 & .2 & .7 & .8 & .6 & .7 & .3 & i.0 & .5 & .6 & 8 & 1.2 \\
\hline $\mathbf{A l}_{2} \mathbf{O}_{3}$ & 20.1 & 16.6 & 19.3 & 22.1 & 22.5 & 2.2 & 10.7 & 13.7 & 9.6 & 12.0 & 4.8 & 23.4 & 14.1 & 15.9 & 17.5 & 15.6 \\
\hline $\mathrm{Fe}_{2} \mathrm{O}_{3}$ & 4.5 & 3.9 & 4.3 & 8.1 & 6.7 & .0 & 1.9 & 3.0 & .8 & 3.4 & .2 & 9.8 & 6.8 & 5.1 & 2.1 & 10.7 \\
\hline $\mathrm{FeO}$ & 2.0 & 1.7 & 2.1 & .7 & .7 & .2 & .5 & 1.0 & .6 & .4 & 3 & .4 & 1.4 & 2.5 & 6.0 & 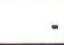 \\
\hline MnO & .0 & .2 & .1 & .0 & .0 & .0 & .0 & .0 & .0 & .0 & .0 & .0 & .0 & .1 & .1 & .1 \\
\hline MgO & 1.8 & 3.4 & 2.1 & 1.0 & 1.0 & .0 & .6 & .7 & .4 & .5 & .1 & .7 & 2.0 & 2.4 & 4.8 & 9.5 \\
\hline $\mathrm{CaO}$ & .3 & 3.8 & 2.2 & .2 & .1 & .0 & .4 & .1 & .1 & .1 & .0 & .2 & .2 & .2 & 1.3 & .6 \\
\hline $\mathrm{Na}_{2} \mathrm{O}$ & 1 & .0 & .0 & .0 & .0 & .0 & .1 & .1 & .1 & .1 & .0 & .0 & .0 & .0 & 1.9 & 1.1 \\
\hline $\mathbf{K}_{2} \mathbf{O}$ & 4.7 & 3.9 & 4.3 & 3.3 & 3.2 & 1.3 & 3.3 & 4.0 & 3.5 & 3.2 & 1.3 & 2.6 & 4.1 & 5.8 & 4.4 & 3.7 \\
\hline $\mathbf{P}_{2} \mathbf{O}_{5}$ & .0 & .1 & .1 & 1 & .1 & .0 & .0 & .1 & .0 & .1 & .0 & .2 & .1 & .1 & .1 & .3 \\
\hline $\mathrm{H}_{2} \mathrm{O}$ & 7.8 & 6.0 & 7.2 & 8.2 & 7.9 & 3 & 3.0 & 4.2 & 2.6 & 4.0 & 1.7 & 10.4 & 4.7 & 4.6 & 4.0 & - \\
\hline $\mathrm{CO}_{2}$ & 2.6 & 6.2 & 3.5 & .2 & .2 & .2 & .4 & .3 & .2 & .2 & 2 & .2 & .2 & .2 & .7 & 5 \\
\hline $\mathbf{s}$ & .0 & .0 & .0 & .0 & .0 & .0 & .0 & .0 & .0 & .0 & .1 & .0 & .0 & .0 & .9 & .2 \\
\hline TOTAL & 102 & 101 & 101 & 97.8 & 98.6 & 99.2 & 99.2 & 99.4 & 99.3 & 99.4 & 99.7 & 99.4 & 98.3 & 989 & 99.6 & 93.9 \\
\hline CIA & 79.4 & 79.5 & 80.2 & 84.8 & 85.7 & 60.6 & 74.4 & 74.5 & 70.8 & 76.0 & 76.8 & 88.1 & 74.9 & 70.7 & 63.0 & 69.3 \\
\hline
\end{tabular}

Rocks: VSh $=$ violet shale, $\mathrm{RSh}=$ red shale, $\mathrm{Ss}=$ sandstone, Slst $=$ siltstone, $\mathrm{Kaoc}=$ kaolinitic clay, Sapr = saprolite, $\mathrm{WMgn}=$ weathered mica gneiss, $\mathrm{Mgn}=$ mica gneiss, $\mathrm{Dbx}=$ dike breccia. Total iron for $\mathrm{Dbx}(189.4 \mathrm{~m})$ as $\mathrm{Fe}_{2} \mathrm{O}_{3}$.

CIA $=$ chemical index of alteration (Nesbitt \& Young 1982)

grabens, which were surrounded by northeast or northwest trending fracture zones (Salop 1983). The nearest examples are grabens of Ladoga, Muhos and Satakunta (Simonen 1980; Kohonen et al. 1993). Peneplanized land, hot humid climate, and abundance of carbon dioxide and oxygen in the atmosphere promoted intense weathering. Red beds are exceptionally widespread among the Late
Riphean sediments (Salop 1983).

The Late Riphean Iso-Naakkima sediments were deposited unconformably on weathered $\mathrm{Pa}$ leoproterozoic mica gneiss. Kaolinization of plagioclase, formation of haematite and loss of $\mathrm{Mg}$, $\mathrm{Ca}$ and $\mathrm{Na}$ in saprolite are evidence of chemical weathering in oxidizing conditions (Table 2, cf. Loughnan 1969). Only the basal part of saprolite 
has been preserved from erosion. Kaolinitic clay and high kaolinite content in sediments (cf. Störr et al. 1978), moderately high CIA-indexes (cf. Nesbitt and Young 1982), and pure quartz sandstones (cf. Franzinelli and Potter 1983) indicate that lateritic weathering took place in a warm and humid climate.

Kaolinized mica gneiss pebbles in conglomeratic sandstone show that kaolinization started before sedimentation. High kaolinite content in shale and a paucity of smectite prove that the provenance of sediments was continental and indicate that sediments accumulated in a continental environment or near the shoreline, because kaolinite usually decreased with increasing distance from shore (Millot 1970; Chamley 1989).

The Iso-Naakkima sequence is $c a .100$ metres thick, of which about $70 \%$ is composed of fine sediments; silt and clay. The whole sequence fines upwards and includes at least three cycles. Upward fining cycles occur for instance in braided and meandering river deposits (Allen 1970; Selley 1970; Collison 1986), and some near shoreline (tidal flat) deposits (Selley 1970; Elliot 1986). The sequence can also be caused by tectonic movement (subsidence of basin) or sea-level variation (transgression, Reading 1986). A thick deposit of laminated clay (shale) in the Iso-Naakkima sequence suggests accumulation in a rather deep basin.

The following facies interpretation is tentative because some primary structures are very difficult to identify from drill cores.

In the Iso-Naakkima sequence matrix-supported conglomeratic sandstone is composed of slightly reworked saprolitic material. This poorly sorted rock could have originated from a debris flow.

Quartz sandstone is typically moderately sorted, rounded, medium- to coarse-grained with kaolinitic clay interbeds and chips. Siltstone is red, massive, laminated, disturbed or rippled rock with sandy and clay interbeds. The primary features of both rock types fit a river (meandering river or perhaps delta) than shoreline deposit (cf. Selley 1970; Pettijohn 1975; Collinson 1986). In a meandering river system, quartz sandstone represents ancient channel floor and point bar deposits, and finer sediments

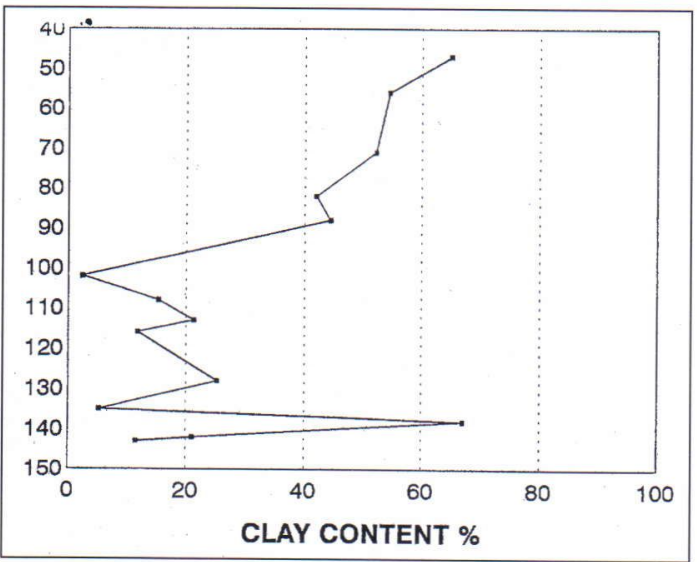

Fig.14. Variation of clay content in the Iso-Naakkima sedimentary rocks shows upward-fining trend. Determined by the Sedigraph particle analyzer (Micrometrics 5000 D) at the GSF.

floodplain deposits.

Red and violet laminated, fissile shales were originally accumulated as clay in a rather deep, quiet, isolated basin; a lake or lagoon, where depositional conditions were transgressive as a result of basin subsidence. The missing of cyclicity in laminations (Selley 1970; Allen and Collison

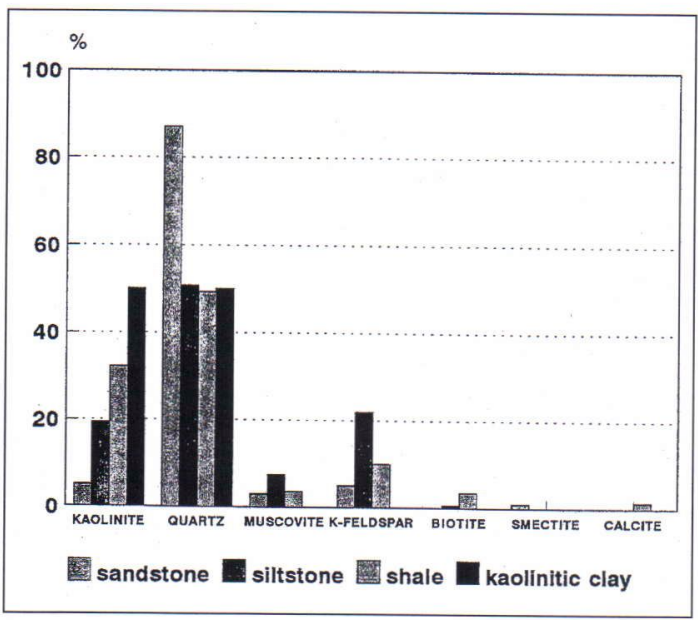

Fig.15. Mineral composition of the Iso-Naakkima sedimentary rocks determined by the Philips X-ray diffractometer (PW 1730) at the GSF and by the pointcounting method (sandstones). 


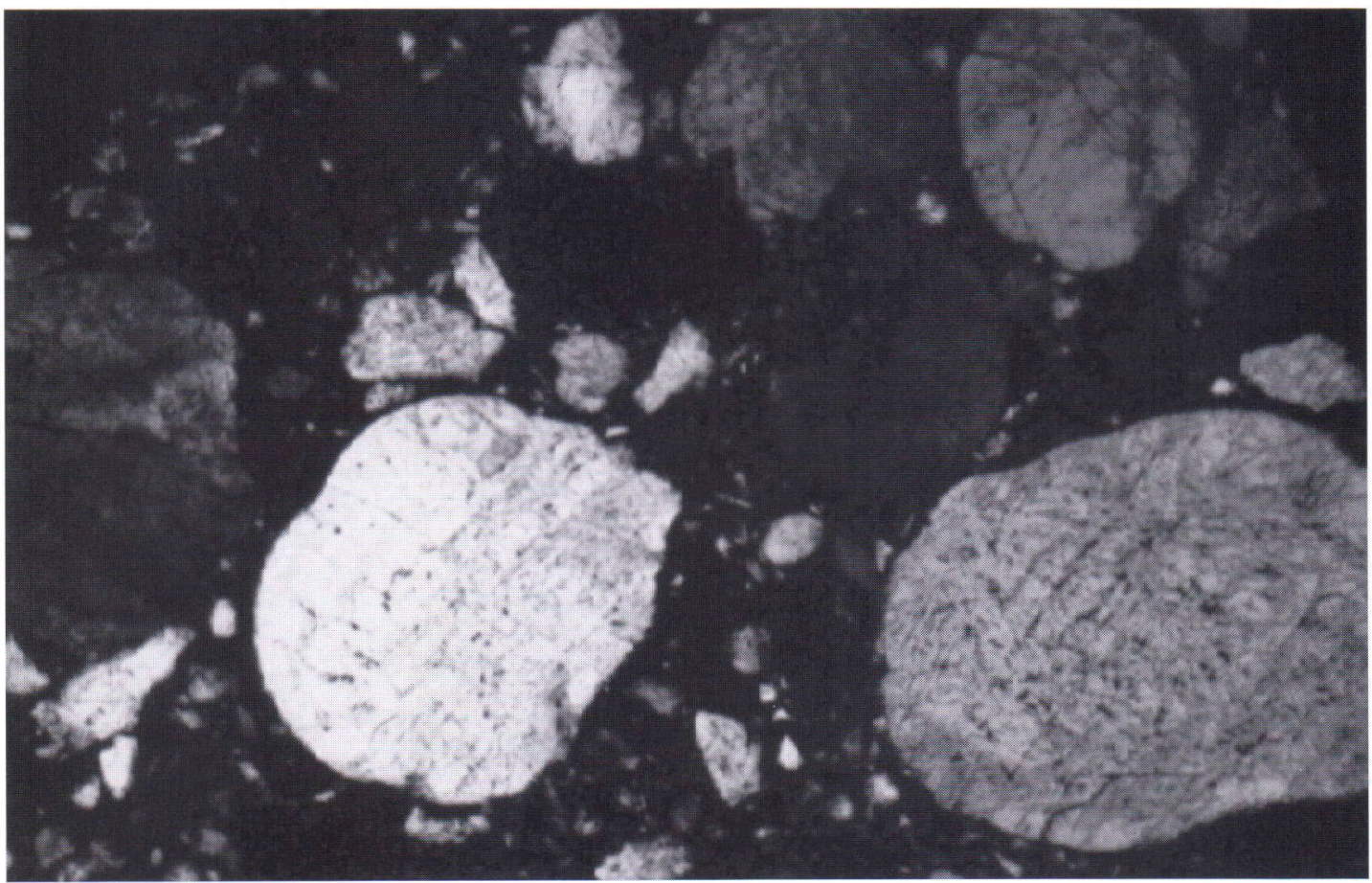

Fig.16. Conglomeratic sandstone with rounded quartz clasts full of planar deformation features (PDFs). DH 385, depth $141.35 \mathrm{~m}$. Crossed polars. The horizontal edge of the figure is $1.7 \mathrm{~mm}$.

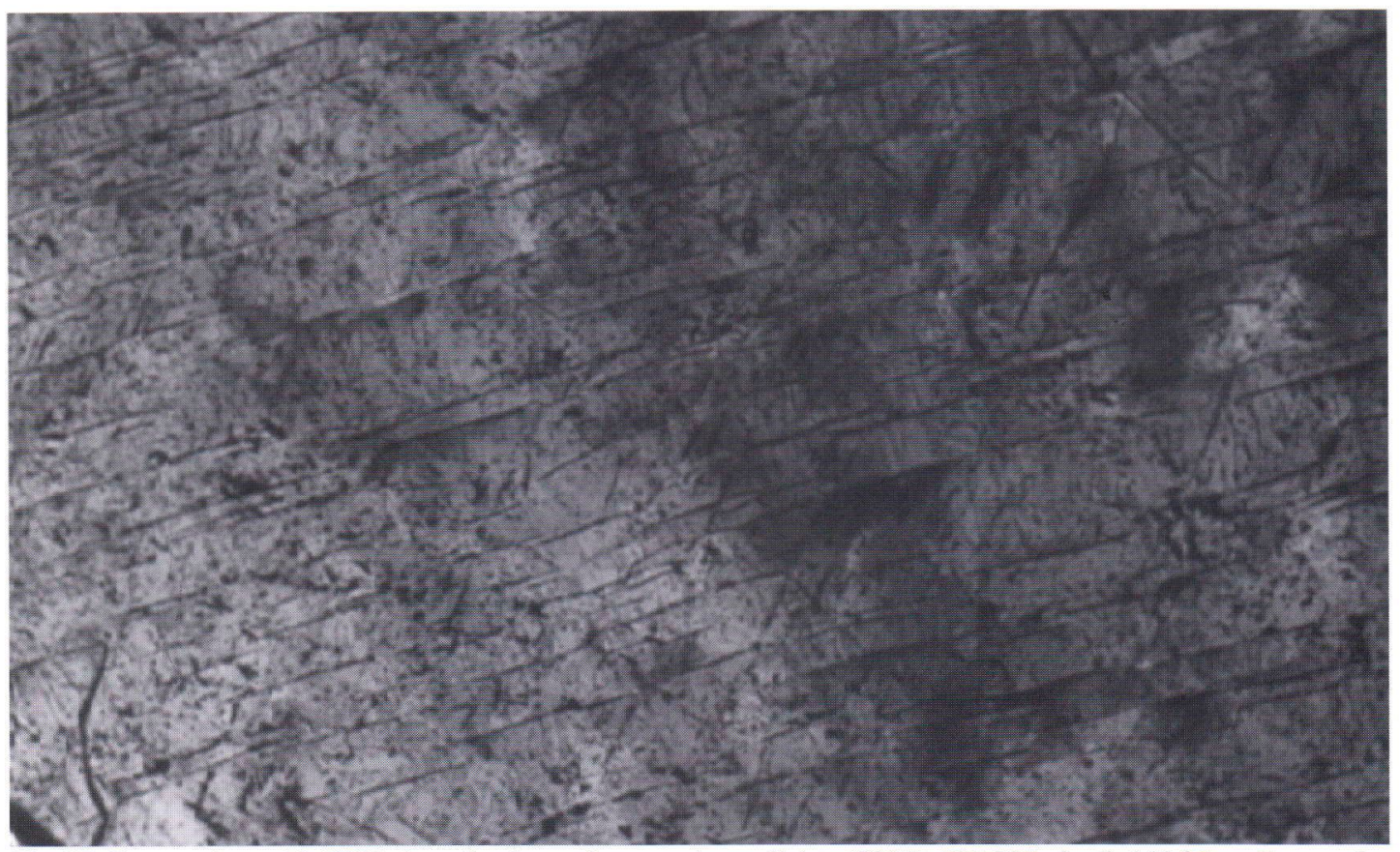

Fig.17. Quartz clast with PDFs (mostly planar fractures) parallel to (0001). DH 385, depth $141.35 \mathrm{~m}$. Crosssed polars. The horizontal edge of the figure is $0.69 \mathrm{~mm}$. 


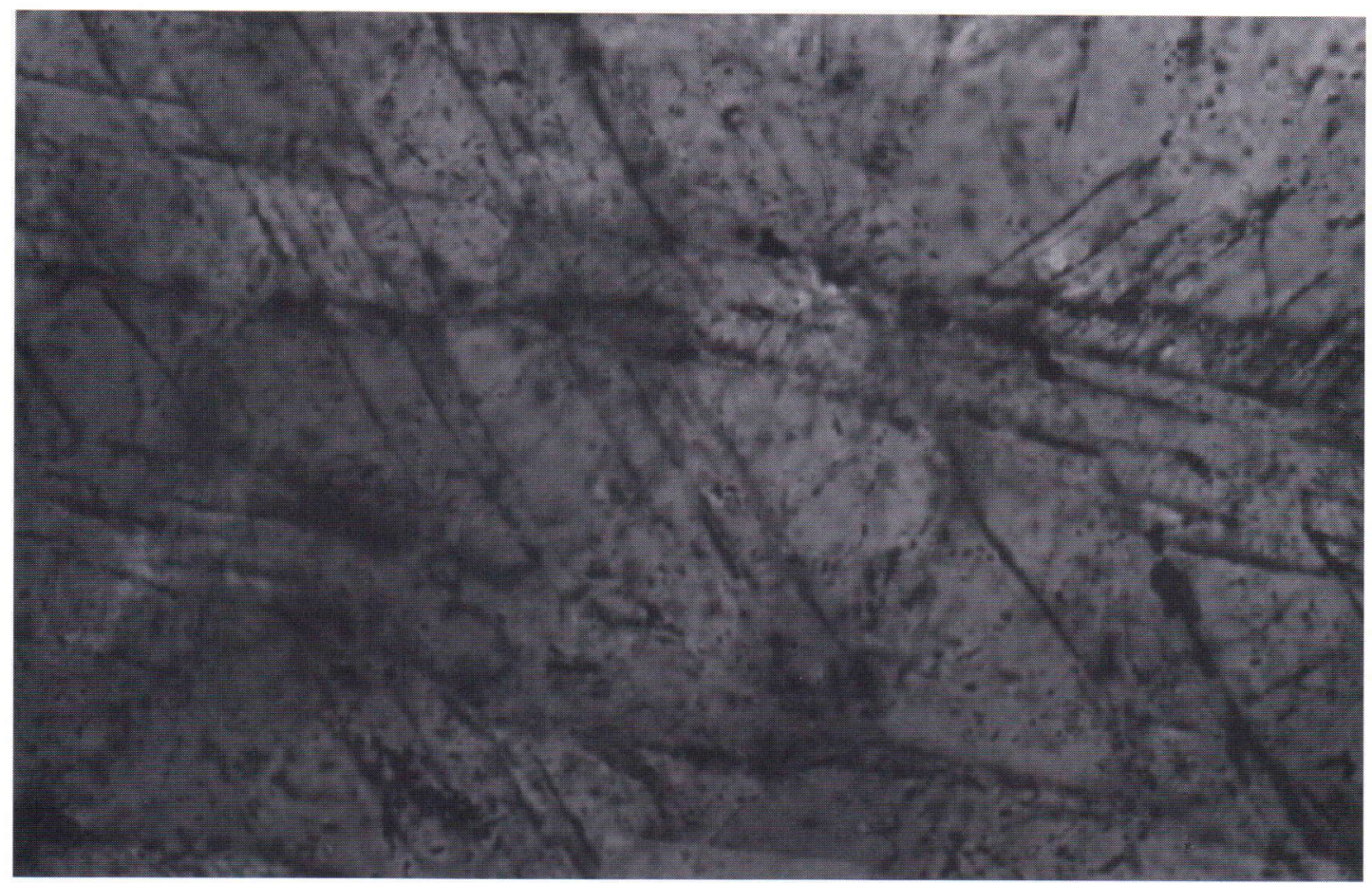

Fig.18. Part of the quartz clast in Fig. 17 showing PDFs. See text for details. Crossed polars. The horizontal edge of the figure is $0.42 \mathrm{~mm}$.

1986) and the microfossil assemblage (see below) indicate that a lagoon is more feasible than a lake environment.

Tilted, brecciated and distorted layers in sedimentary rocks indicate postdepositional subsidence of the Iso-Naakkima basin, which obviously preserved the sediments from later erosion.

\section{EVIDENCE OF SHOCK METAMORPHISM}

The shock-metamorphic features observed in certain Iso-Naakkima rocks are of a fundamental nature when the origin of the structure is considered. At Iso-Naakkima, the evidence of shock metamorphism includes planar deformation features in quartz, kink bands in micas (biotite and muscovite) and the occurrence of polymictic dike breccia.

\section{Planar deformation features in quartz}

The best-developed shock-metamorphic features in the Iso-Naakkima rocks are observed in the quartz of the matrix-supported conglomeratic sandstone from DH 385 at a depth of $141.35 \mathrm{~m}$. At this level the rock is reddish grey in colour and contains some angular clasts of mica gneiss and siltstone up to $2.5 \mathrm{~cm}$ in diameter.

In thin section, all the larger quartz clasts are well-rounded or rounded and full of planar deformation features (PDFs) (Figs. 16 - 18). The dominant feature of the Iso-Naakkima quartz with PDFs is, in this and the other rocks, too, that most of them are planar fractures and parallel or subparallel to (0001). There are, so far, no accurate measurements with universal stage techniques but the measured (estimated) steep angles to the c-axis of quartz ( $\mathrm{ca} .50^{\circ}$ and $\left.90^{\circ}\right)$ seem to indicate PDFs 
parallel to $\{10 \overline{1} 1\}$ or $\{11 \overline{2} 2\}$ and $\{10 \overline{1} 0\}$, respectively. The presence of $\{10 \overline{1} 3\}$-orientation, generally common in shocked quartz, is indicated by ease of finding of PDFs with angles of about $20^{\circ}$ to the c-axis. These measured PDF orientations are fairly typical for low shock pressures of $c a .20 \mathrm{GPa}$. They are observed e.g. in experimentally shocked quartz from Tensleep sandstone (Short 1968, p. 232; see also Alexopoulos et al. 1988 and Langenhorst et al. 1992).

Also typical of the PDFs observed in the IsoNaakkima rocks is that, although there are multiple sets of PDFs in a single grain or clast, the (0001)oriented planar features are short and bent. This feature is not very typical to quartz from known impact sites (cf. Alexopoulos et al. 1988). A small displacement is commonly associated with the (0001)-orientation (Fig. 17). The PDFs steeply inclined to the c-axis are also short or very short: they may exist just between two (0001)-oriented planar fractures. They can also form half featherlike features with a (0001)-oriented fracture as a shaft (Fig. 18). Unlike other PDFs in the IsoNaakkima quartz, the $\{10 \overline{1} 3\}$-orientation consists of very thin and closely spaced planar elements (cf. the Lake Lappajärvi quartz, Fig. 10 in Lehtinen 1976). These thin planar elements are also straight, parallel and longer than the other PDFs observed in the Iso-Naakkima quartz.

Rocks underlying the conglomeratic sandstone at $141.35 \mathrm{~m}$ contain varying amounts of quartz grains with PDFs, too. However, the sedimentary rocks above this "critical horizon" in the IsoNaakkima sequence do not have quartz with PDFs. The saprolitic sandstone at $141.5 \mathrm{~m}$ has a few coarse-grained, angular quartz grains or fragments (clasts) with plenty of the typical (0001)-oriented planar features. Most of the quartz in the rock, however, is clear and only broken or has wavy extinction.

At $142.75 \mathrm{~m}$, the saprolitic rock is an altered mica gneiss with medium-grained quartz veins. It is only the quartz of these veins that shows PDFs with typical sets of short, curved (0001)-fractures. Brecciated mica gneiss at $155.8 \mathrm{~m}$ and veined mica gneiss at $178.3 \mathrm{~m}$ have only a few quartz grains and fragments that show some PDFs.

Also feldspar fragments and grains of the rocks described may show some weak signs of shock but the very common kaolinization of feldspars in the Iso-Naakkima rocks hampers reliable observations.

\section{Kink bands}

The occurrence of kink bands in micas of tectonically deformed rocks is well-known and, thus, the kink bands are not exclusively caused by shock. Some of the Iso-Naakkima specimens are, however, conspicuously rich in kink bands (Fig. 19). Especially in rocks containing quartz with PDFs, kink bands are almost omnipresent in single grains of mica (mostly biotite) and in biotite (+ muscovite) grains of mica gneiss and granite fragments. The amount of kinked mica decreases downwards in the drill core, and e.g. at $178.3 \mathrm{~m}$ they are observed only at certain strongly fractured or deformed layers of the mica gneiss.

\section{Dike breccia}

A strongly brecciated (cataclastic) rock with dark clasts, almost black in thin sections, is interpreted as a dike breccia (injection dike breccia). The rock is found as veins in the drill core (DH 385) at a depth of $189.6 \mathrm{~m}$ and also at $155.8 \mathrm{~m}$.

Rock fragments of the dike breccia are mica gneiss (also garnet- and sillimanite-bearing varieties) and granite. Some mica gneiss fragments show strong kaolinization of feldspars and chloritization of biotite. The main mineral fragments are quartz, feldspars, biotite and muscovite. The accessory minerals (fragments) are apatite, zircon, garnet, opaques and chlorite. Signs of weak shock metamorphism are evident: some quartz grains show short but clear PDFs or are mosaic-like in texture, and fragments of mica are full of kink bands.

The texture of the dike breccia is characterized by the angular fragments embedded in very finegrained matrix. Most of the fragments are strongly 


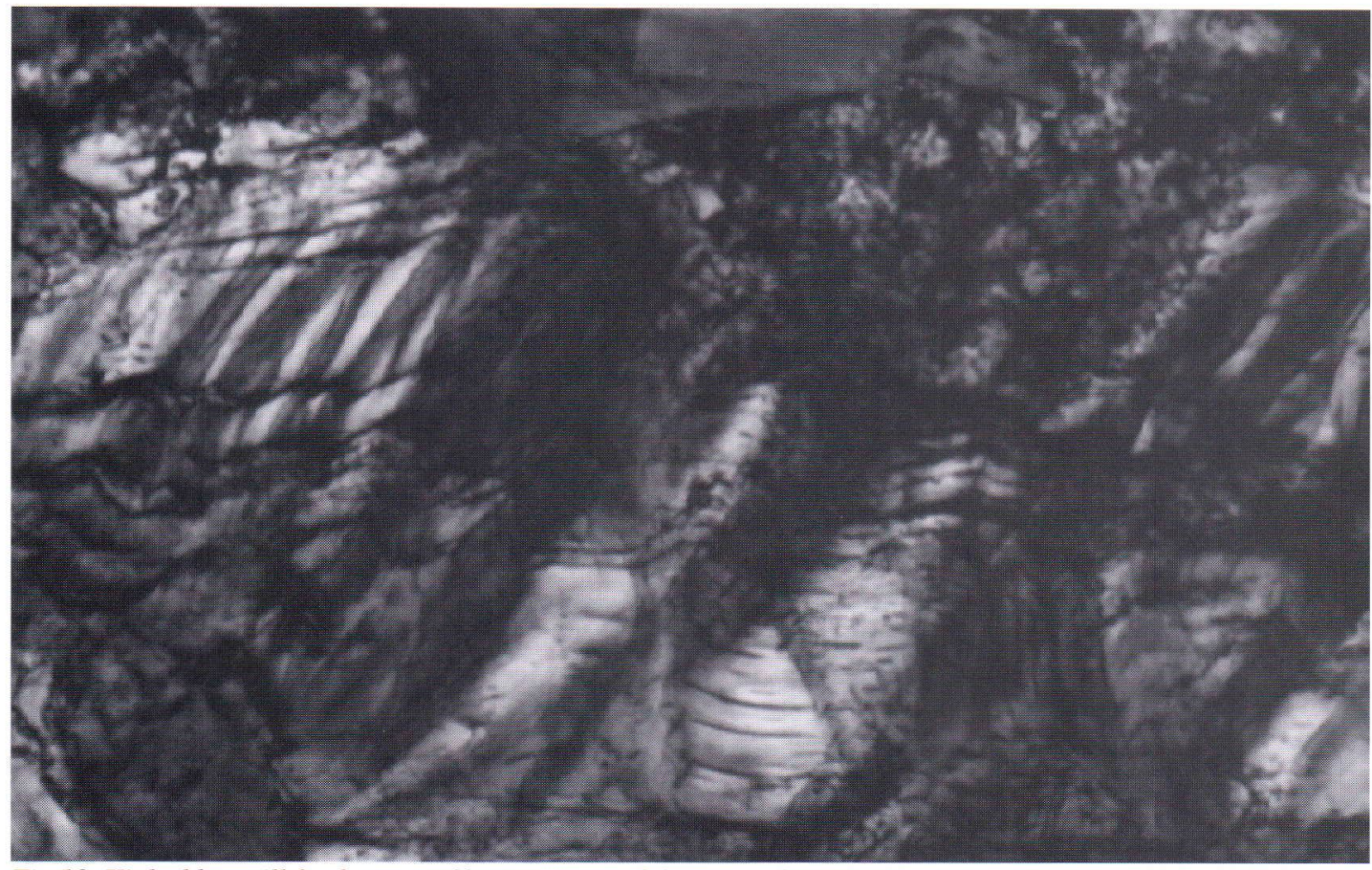

Fig.19. Kinked but still fresh grain of biotite (most of the intensely kinked biotite grains are strongly weathered). Dike breccia. DH 385, depth $189.60 \mathrm{~m}$. Plane polarized light. The horizontal edge of the figure is $0.42 \mathrm{~mm}$.

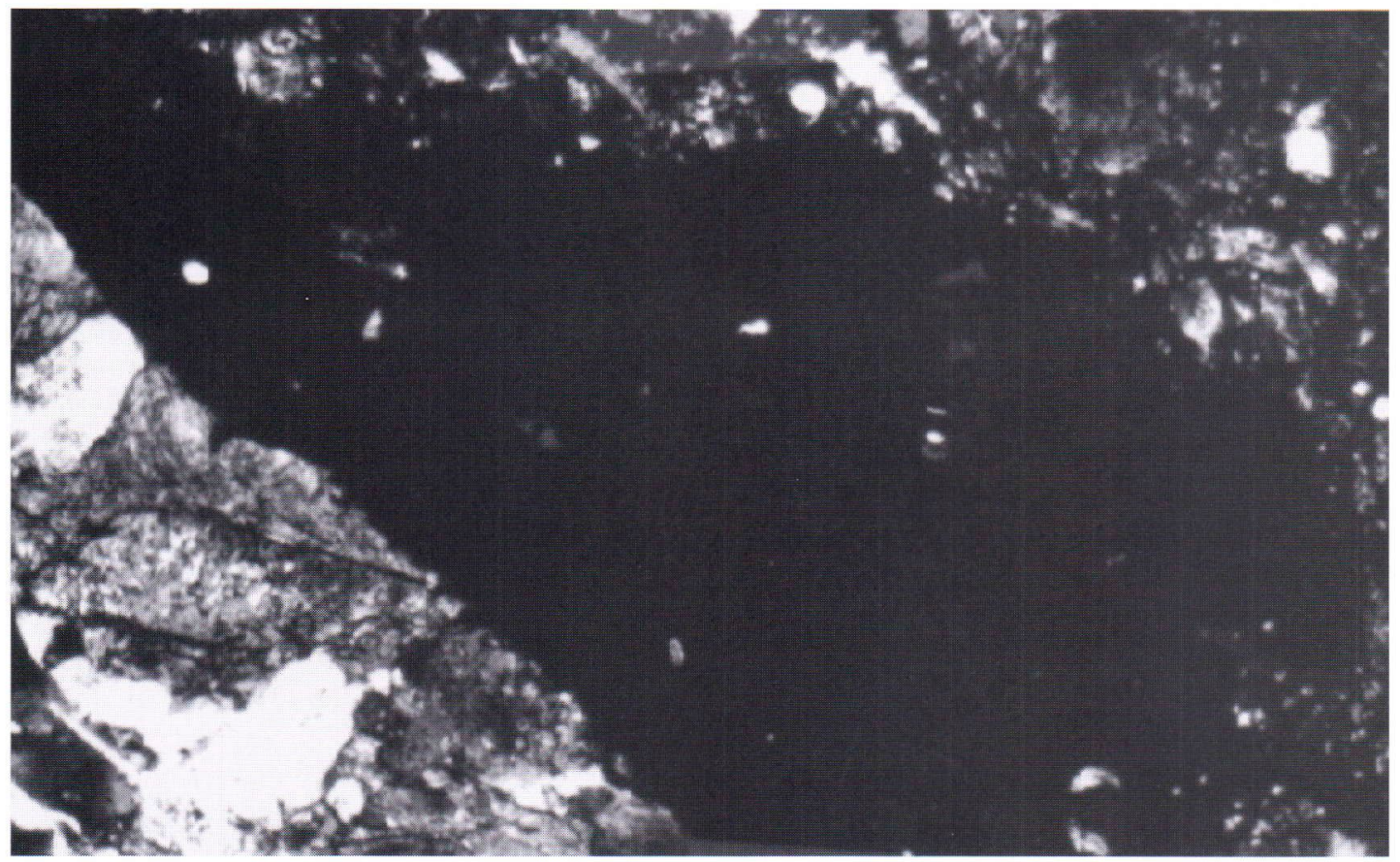

Fig.20. Dike breccia. A clast consisting of mica gneiss sharply cut by dark glassy-like material. DH 385, depth $189.60 \mathrm{~m}$. Crossed polars. The horizontal edge of the figure is $1.7 \mathrm{~mm}$. 


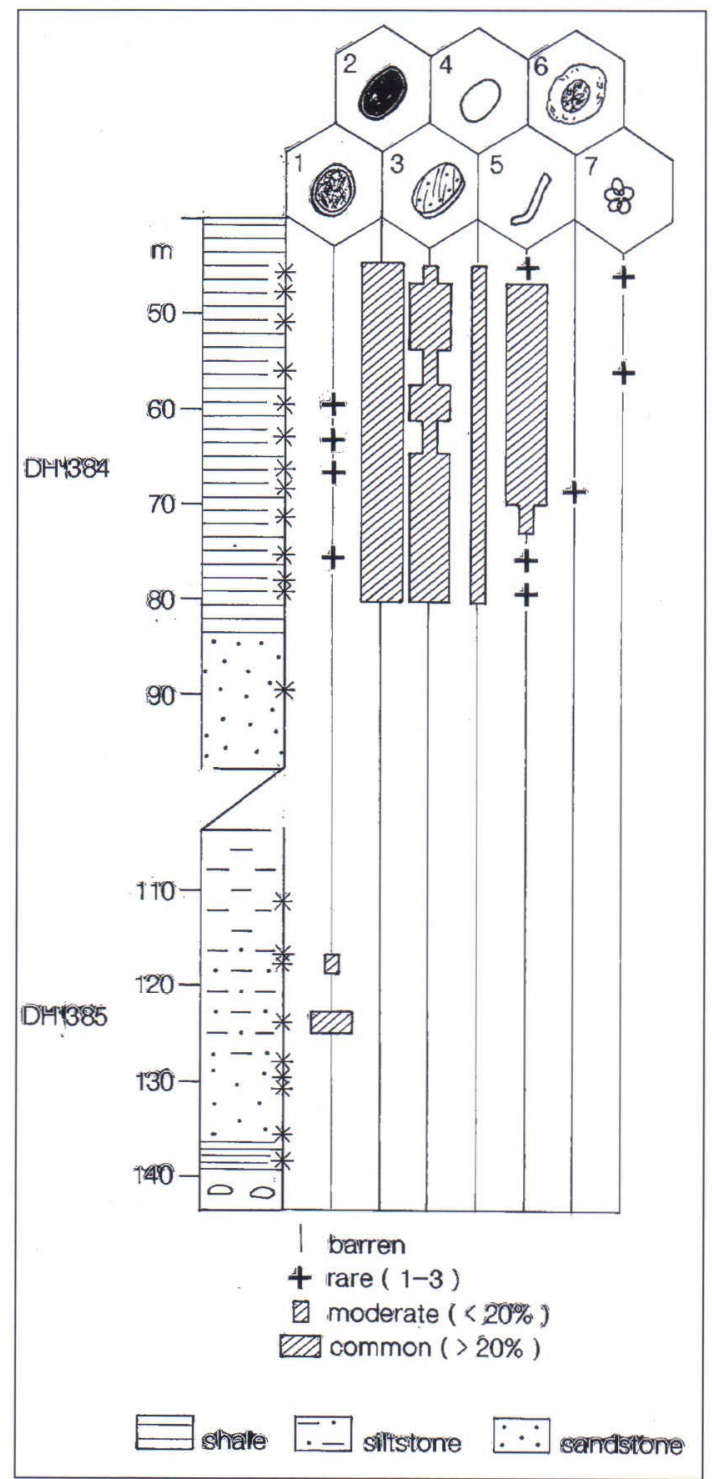

Fig.21. The range of species at various depths in the DH 384 and 385. 1. Spumosina rubiginosa; 2. Leiosphaeridia crassa; 3. Leiosphaeridia exsculpta; 4. Leiosphaeridia minutissima; 5. Fragments of empty sheaths; 6. Pterospermopsimorpha granulata; 7. Symplassosphaeridium parvum.

crushed and seem to be broken off the mica gneiss by frictional process indicative of violent movement of rock debris.
The dark fragments are usually angular and from one to two $\mathrm{mm}$ in diameter but fragments up to 8 $\mathrm{mm}$ in length have also been observed. The fragments contain very small mineral inclusions and aggregates of broken minerals (Fig. 20) embedded in an extremely fine-grained glassylooking (or clayey) dark (almost black) matrix. The dark matrix shows dark brown or brown bands.

At first glance, the dark fragments may resemble the glassy fragments of e.g. the Lake Lappajärvi suevite (Lehtinen 1976). However, these fragments are not vesiculated like the glassy fragments (lapilli) of suevite. In addition, some of the fragments still adhere to (Fig. 20) or even penetrate mica gneiss fragments broken off the walls of the vein. The dark fragments are explained here as pieces of broken pseudotachylyte (cf.Philpotts 1964; Maddock 1986) formed by extreme mylonitization (but mainly without frictional fusion).

The Iso-Naakkima dike breccia closely resembles the vein-like breccias (polymictic injection breccias) observed in the 1973 Ries research drill core even $600 \mathrm{~m}$ below the crater floor (Chao 1977; Stöffler 1977). The Ries dikes are interpreted to be dilation injection dikes produced during the crater growth. The so-called pseudotachylites from the central uplift of the Lake St. Martin impact structure, Canada, are also concluded to be injected impact breccia (Reimold et al. 1990).

\section{MICROFOSSILS}

A total of 22 samples were processed and studied from boreholes DH 384 (45.35 m - $89.35 \mathrm{~m})$ and DH 385 (111.40 m - $137.90 \mathrm{~m})$. This was done in order to establish the biochronostratigraphical control of the sediments investigated.

In a maceration process $\mathrm{HF}$ and $\mathrm{HCl}$ were used and Sodiumpolytungstate as a heavy liquid. Microfossils were found in 14 samples of which six contained abundant acritarchs (more than 200 acritarchs per one sample), while eight were barren. The present ranges of the species and their occurence at various depths in the core are presented in Figure 

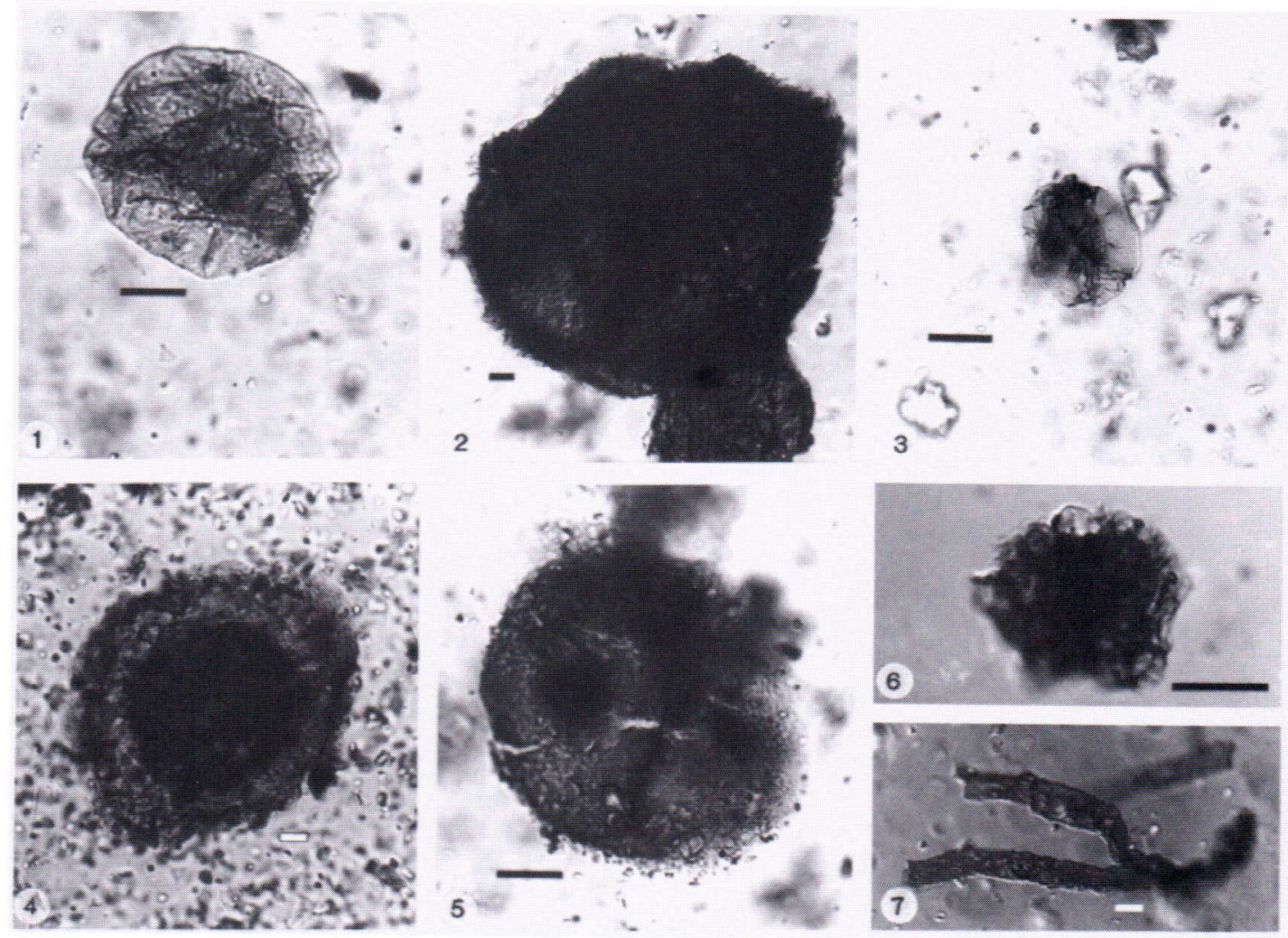

Fig.22. 1. Leiosphaeridia crassa (Naumova) Lindgren 1982 (DH 384, depth $62.00 \mathrm{~m}$ ). 2. Leiosphaeridia exsculpta (Timofeev) Mikhailova 1989 (DH 384, depth 50.60 m). 3. Leiosphaeridia minutissima (Naumova) Yankauskas 1989 (DH 384, depth 50.60 m). 4. Pterospermopsimorpha granulata Mikhailova 1989 (DH 384, depth 67.67 m). 5. Spumosina rubiginosa (Andreeva) Yankauskas \& Mikhailova 1989 (DH 384, depth 62.00 m). 6. Symplassosphaeridium parvum Tynni 1978 (DH 384, depth $45.35 \mathrm{~m})$. 7. Fragments of empty sheath (DH 384 , depth $50.60 \mathrm{~m}$ ). Bar equals $10 \mathrm{~mm}$.

21.

The diversity of taxa was low and the assemblage includes only sphaeromorphs and fragments of empty sheaths:

- Leiosphaeridia crassa (Naumova) Yankauskas 1989: a smooth, thick-walled, spherical, dark yellow to light brown vesicle or cluster of vesicles ( Ø6 $150 \mu \mathrm{m}, \mathrm{x}=26.0 \mu \mathrm{m}, \mathrm{N}=1000$ ). Fig. 22:1. Leiosphaeridia asperata (Naumova) Lindgren 1982, Kildinella hyperboreica Timofeev 1966 and Kildinosphaera shagrinata Vidal 1983 were regarded as synonyms of Leiosphaeridia crassa (Yankauskas et al. 1989).
- Leiosphaeridia exsculpta (Timofeev) Mikhailova 1989: a dark brown, slightly granular, thick-walled spherical vesicle or cluster of vesicles (Ø15 - $255 \mu \mathrm{m}, \mathrm{x}=38.4 \mu \mathrm{m}, \mathrm{N}=738$ ). Fig. 22:2.

- Leiosphaeridia minutissima (Naumova) Yankauskas 1989: a smooth, thin-walled spherical vesicle or cluster of vesicles, light yellow to light brown in colour ( $99-105 \mu \mathrm{m}, \mathrm{x}=38.2 \mu \mathrm{m}, \mathrm{N}=$ 201). Fig. 22:3.

- One Pterospermopsimorpha granulata Mikhailova 1989: a thick-walled granulate spherical vesicle has equatorially a thin-walled granulate membrane $(\varnothing 70 \mu \mathrm{m}$, membrane width $30 \mu \mathrm{m}$, total 
$\varnothing 140 \mu \mathrm{m})$. Fig. 22:4.

- Spumosina rubiginosa (Andreeva) Yankauskas and Medvedeva 1989: a thick-walled sphaeromorph with a meshy surface, opaque to dark brown in colour. A medial split was also recorded ( $\varnothing 20$ - 60 $\mu \mathrm{m}, \quad \mathrm{x}=30.1 \mu \mathrm{m}, \mathrm{N}=19$ ). Fig. 22:5. Protosphaeridium flexuosum Timofeev 1966: it has been included the species and according to the original diagnosis its diameter is smaller than 60 $\mu \mathrm{m}$. Also Orgymatosphaeridium rubiginosum (Andreeva 1966) is a synonym of Spumosina rubiginosa.

- Three Symplassosphaeridium parvum Tynni 1978: a tightly packed cluster of smooth, thinwalled, light brown small cells ( $\varnothing$ of a cell $4 \mu \mathrm{m}$, total $\varnothing 18-20 \mu \mathrm{m})$. Fig. 22:6.

- Fragments of light yellow to light brown, smooth, thin-walled, unbranched and non-septate empty sheaths (width $2-20 \mu \mathrm{m}$, the most common width $9 \mu \mathrm{m}$, length $2-980 \mu \mathrm{m}$, medium length 99 $\mu \mathrm{m}, \mathrm{N}=222$ ). Fig. 22:7.

- No macrofossils were present.

The microfossil assemblage indicative of the Late Riphean (1000-650 Ma) consists exclusively of sphaeromorphic achritarch taxa, while that of Early Vendian (650-640 Ma) also includes polygonomorphic and double walled acritarchs (Vidal and Knoll 1983), as well as multicellular and spiralous filaments (Tynni and Donner 1980; Tynni and Uutela 1985; Yankauskas et al. 1989; Volkova 1990).

In the present material dominance of Leiosphaeridia crassa and minority of Leiosphaeridia minutissima with the presence of Leiosphaeridia exsculpta and Pteropermopsimorpha granulata suggest Late Riphean age, as well as do species Spumosina rubiginosa (Yankauskas et al. 1989) and Symplassosphaeridium parvum (Tynni 1978; Tynni and Uutela 1984).

The low specific diversity of the microfossil assemblage could indicate an inshore and, especially, lagoonal environment (Vidal and Knoll 1982). The effect of thermal alteration is not observable in the well preserved microfossils.

\section{DISCUSSION AND CONCLUSIONS}

The microfossil assemblage found in sediments investigated suggests that the Iso-Naakkima deposits were most probably laid down during the Late Riphean, i.e. 1000 - 650 Ma ago (Chumakov and Semikhatov 1981).

In other parts of Finland, Mesoproterozoic Jotnian or Middle Riphean nonmetamorphic sediments occur in downfaulted blocks of the Precambrian basement in Satakunta and Muhos (Fig. 1) (Veltheim 1969; Simonen and Kouvo 1954; Simonen 1980; Tynni and Uutela 1984; Kohonen et al. 1993). The K-Ar age of the Satakunta sandstone and Muhos sediments is $1300-1400 \mathrm{Ma}$ (Simonen 1980), although the microfossil assemblage suggests that the age is $1200 \mathrm{Ma}$ (Tynni and Uutela 1984). The downfaulting of the Muhos graben is nearly one kilometer and that of the Satakunta graben at least $650 \mathrm{~m}$. The nearest Riphean sediments crop out or are covered by younger sediments in the Lake Ladoga depression (Gorbunov and Papunen 1985) ca. $200 \mathrm{~km}$ SE of the Iso-Naakkima sequence. Also in other parts of Russia Riphean sediments are common (Chumakov and Semikhatov 1981).

Identified circular crater-like basins in Finland with Neoproterozoic or Lower Paleozoic sedimentfill are Söderfjärden (Laurén et al. 1978; Lehtovaara 1982, 1990), Lake Lappajärvi (Lehtinen 1970, 1976; Pipping and Lehtinen 1992) and Lake Saarijärvi (Tynni and Uutela 1985). A meteorite-impact origin based e.g. on structural, petrographic, mineralogical and geochemical evidence is suggested for two of these basins namely Lake Lappajärvi and Söderfjärden (Pipping and Lehtinen 1992, and references therein; Lehtovaara 1982).

When considering the origin of the Iso-Naakkima basin, the circular shape of the basin is the most conspicuous feature. The possible origins for circular basin shape include a) a combination of crosscutting sets of faults, b) a pull apart in releasing bend along a strike-slip fault, and subsequent weathering, c) weathering (or subsidence) of a pipe-like intrusive body, d) meteorite impact. 
Satellite imagery shows that the Iso-Naakkima formation is situated along a prominent lineament that continues from Iso-Naakkima for about 150 $\mathrm{km}$ in both the NW and SE directions. Other linear features are not so striking in the area, obviously due to the masking effect of glacial drift. However, it is not possible to pinpoint any certain linear feature, which crosscuts the previously mentioned lineament exactly at the site of the gravity minimum.

No volcanic rocks or marks of volcanic activity exist in the rocks at the bottom of the basin or in the drill cores. Therefore the volcanic origin of the basin (structure) is excluded. On the other hand, the observed shock-metamorphic features in quartz and biotite of the conglomeratic sandstone, the saprolite, the altered mica gneiss and also the occurrence of the dike breccia, almost $50 \mathrm{~m}$ below the saprolite, suggest a meteorite impact origin for the basin as the most possible explanation.

According to available crater statistics (e.g. Melosh 1989), a total amount of 40 or 50 craters with diameters from $2 \mathrm{~km}$ to $3 \mathrm{~km}$ should have formed during the Neoproterozoic on the land surface of Finland. No such structure has so far gained the status of a proven impact crater in Finland (see e.g. Henkel and Pesonen 1992), although some of the basins have been tentatively suggested as possible impact craters. As e.g. Grieve (1991) states, at small diameters the number of known terrestrial craters falls below the expected distribution, because old small craters are relatively more (deeply) eroded and harder to recognize than larger ones.

Considering the Iso-Naakkima structure as a meteorite impact site, it may be surprising that no breccia lenses have been found, unless the lowest sedimentary rocks can be reinterpreted as a kind of weathered and redeposited breccia. According to Melosh (1989), fresh simple craters on all planetary bodies are morphologically similar, having depth/ diameters ratios between $1 / 5$ and $1 / 3$, and the maximum thickness of the breccia lens is roughly half of the depth of the transient crater. If we take the diameter of the sedimentary rocks in the IsoNaakkima basin for example, $1.8 \mathrm{~km}$, as an estimate of the crater diameter, the depth of the original crater should have been $360 \mathrm{~m}$ to $600 \mathrm{~m}$ and the maximum thickness of the breccia lens $180 \mathrm{~m}$ to $300 \mathrm{~m}$. This would mean that in the case of IsoNaakkima nearly half of the original crater would have been eroded, and most of the remaining material in the crater should represent the breccia lens. Since most of the crater fill at Iso-Naakkima consists of sedimentary rocks, the description of crater properties given by Melosh (1989) does not apply, or the structure is not a meteorite crater, or, most probably, nearly all the breccia lens has been eroded leaving a depression which subsequently filled with sedimentary rocks.

The study of the subsurface parts of terrestrial meteorite craters of different sizes in various environments (e.g. dry land vs shallow sea, unglaciated vs glaciated areas, small vs large) is still an evolving field. Craters produced by meteorite impacts on sedimentary rocks in shallow marine environments for example, may conceivably differ from the classical dry land model (Melosh 1989). Whether it is possible to interprete the Iso-Naakkima structure as a meteorite impact crater or not, requires the determination of the environment at the time of impact, and a detailed description of the structure effected by a meteorite impact within the proper energy range in this environment. This will be best achieved by examining different craters of this category.

The timing of the possible impact at IsoNaakkima is not resolved yet. Accordingly, the time gap between the impact and the present basin fill is still unknown. However, intense weathering and erosion was needed to level down the impact crater with breccias. The basin, which the IsoNaakkima sediments occupy at present, should be a deeply eroded remnant of a larger impact crater. The initial impact-produced fracturing of the basal part of the crater made it prone to accelerated weathering compared with the surrounding mica gneiss.

The warm and humid climate prior to the deposition of Iso-Naakkima sediments was favorable for intense laterite-type weathering. This 
is indicated by the occurrence of kaolinitic clay, kaolinite in the sedimentary rocks and chemically rather pure quartz sand as discussed above. According to the paleomagnetic data, Fennoscandia occupied temperate southern latitudes during most of the Riphean (Pesonen et al. 1989), a position necessary for rapid chemical weathering.

The sedimentary succession at Iso-Naakkima as a whole refers to a transgression or fining upward with some interruptions (sandstones). The sedimentation was probably alluvial or lacustrine.

Tectonic movements during and after sedimentation are obvious on the basis of the tilted sediments in the Iso-Naakkima basin. Subsidence

\section{REFERENCES}

Alexopoulos, J.S., Grieve, R.A.F. \& Robertson, P.B., 1988. Microscopic lamellar deformation features in quartz: Discriminative characteristics of shockgenerated varieties. Geology 16, $796-799$.

Allen, J.R.L., 1970. Studies in fluviatile sedimentation: a comparison of fining-upwards cyclothems, with special reference to coarse-member composition and interpretation. Journal of Sedimentary Petrology 40, $298-323$.

Allen, P.A. \& Collison, D.J., 1986. Lakes. In: Reading, H.G. (ed.) Sedimentary Environments and Facies. 63 $-94$.

Chamley, H., 1989. Clay Sedimentology. SpringerVerlag, Berlin - Heidelberg, 623 pp.

Chao, E.C.T., 1977. Preliminary interpretation of the 1973 Ries research deep drill core and a new Ries cratering model. Geologica Bavarica 75, 421 - 441.

Chumakov, N.M. \& Semikhatov, M.A., 1981. Riphean and Vendian of the USSR. Precambrian Research 15, $229-253$.

Collison, J.D., 1986. Alluvial sediments. In: Reading, H.G. (ed.), Sedimentary Environments and Facies. $20-62$.

Elliott, T., 1986. Siliciclastic Shotelines. In: Reading, H.G. (ed.), Sedimentary Environments and Facies. $155-188$.

Elo, S., 1989. Regional gravity map series 1989A for microcomputers. Diskette RGMS1989A, Geophysics department, Geological Survey of Finland. 15 different maps on colour, positive grey and negative grey of the formation concurrent with or after the sedimentation explains the preservation of the sedimentary rocks up to the present.

ACKNOWLEDGEMENTS: The airborne geophysics group of the Geological Survey of Finland assisted in the processing of the aerogeophysical data and maps. Tarja Manninen helped greatly in preparing the gravity data. Liisa Kivekäs provided petrophysical data. Tarmo Jokinen, Jukka Lehtimäki and Heikki Soininen together with their associates conducted the wide-bandelectromagnetic investigations. Kristian Lindqvist made the XRD determinations. The figures were drawn by Satu Moberg and Sisko Sulkanen.

To all the above mentioned persons and many others we wish to express our gratitude.

scales.

Elo, S., Jokinen, T. \& Turunen, P., 1983. Saarijärven savikiviesiintymän geofysikaaliset tutkimukset. In: Eskola, L. (ed.), Geofysiikkaa geologeille. Report of Investigations No. 58, Geological Survey of Finland, $101-116$.

Elo, S., Kiveküs, L., Kujala, H., Lahti, S.I. \& Pihlaja, $P .$, 1992. Recent studies of the Lake Sääksjärvi meteorite impact crater, southwestern Finland. Tectonophysics 216, 163 - 167.

Franzinelli, E. \& Potter, P.E., 1983. Petrology, chemistry, and texture of modern river sands, Amazon River system. Journal of Geology 91, 23 - 39.

Gorbunov, G.I. \& Papunen, H. (eds.), 1985. General Geological Map of the Baltic Shield, 1:2 500 000. In: Nickel-copper deposits of the Baltic Shield and Scandinavian Caledonides. Geological Survey of Finland, Bulletin 333, 394 pp.

Grieve, R.A.F., 1991. Terrestrial impact: The record in the rocks. Meteoritics 26, $175-194$.

Henkel, H. \& Pesonen. L., 1992. Impact craters and craterform structures in Fennoscandia. Tectonophysics 216:1/2, 31 - 40.

Kivekäs, $L$. 1993. Density and porosity measurements at the petrophysical laboratory. In: Autio, S. (ed.), Geological Survey of Finland, Current Research. 1991 - 1992. Special Paper 18, 119 - 127.

Kohonen, J., Pihlaja, P., Kujala, H. \& Marmo, J., 1993. Sedimentation of the Jotnian Satakunta sandstone, western Finland. Geological Survey of Finland, Bulletin 369, 35 pp.

Langenhorst, F., Deutsch. A., Stöffler, D. \& Hornemann, U., 1992. Effect of temperature on shock meta- 
morphism of single-crystal quartz. Nature 356, 507 $-509$.

Laurén, L., Lehtovaara, J., Boström, R. \& Tynni, R., 1978. On the geology of the Cambrian sediments of the circular depression at Söderfjärden, western Finland. Geological Survey of Finland, Bulletin 297, 81 pp.

Lehtinen, M., 1970. New evidence for an impact origin of Lake Lappajärvi, western Finland. Bulletin of the Geological Society of Finland 42, 89 - 93.

Lehtinen, M., 1976. Lake Lappajärvi, a meteorite impact site in western Finland. Geological Survey of Finland, Bulletin 282, 92 pp.

Lehtovaara, J., 1982. Stratigraphical section through Lower Cambrian at Söderfjärden, Vaasa, western Finland. Bulletin of the Geological Society of Finland $54,35-43$.

Lehtovaara, J., 1990. Söderfjärden, western Finland - a Cambrian-filled meteorite crater $100 \mathrm{~km}$ west of Lappajärvi. In: Pesonen, L.J. \& Niemisara, N. (ed.): Symposium Fennoscandian impact structures, May 29 - 31, 1990, Espoo \& Lappajärvi, Finland. Programme and abstracts. Geological Survey of Finland, $29 \mathrm{pp}$.

Loughnan, F.C., 1969. Chemical Weathering of the Silicate Minerals. American Elsevier Publ. Co. Inc., New York, 154 pp.

Maddock, R.H., 1986. Partial melting of lithic porphyroclasts in fault-generated pseudotachylytes. Neues Jahrbuch für Mineralogie, Abhandlungen 155, 1 - 44.

Melosh, H.J., 1989. Impact Cratering - A Geologic Process. Oxford University Press, New York, 245 pp. Millot, G., 1970. Geology of Clays. Weathering. Sedimentology. Geochemistry. Springer-Verlag. New York. 428 pp.

Nesbitt, H.W. \& Young, G.M., 1982. Early Proterozoic climates and plate motion inferred from major element chemistry of lutites. Nature 299, 715 - 717.

Pesonen, L.J., Torsvik, T.H., Elming, S. \& Bylund, G., 1989. Crustal evolution of Fennoscandia paleomagnetic constraints. Tectonophysics 162, 27 49.

Pettijohn, F.J., 1975. Sedimentary rocks. Harper \& Brothers, New York, 718 pp.

Philpotts, A.R., 1964. Origin of pseudotachylites. American Journal of Science 262, 1008 - 1035.

Pipping, F., 1992. Lappajärvi impact crater: drilling continued. In: Autio, S. (ed.), Geological Survey of Finland, Current Research 1989 - 1990. Special Paper 12,33 - 36.

Pipping, F. \& Lehtinen, M., 1992. Geology, stratigraphy and structure of the Lappajärvi meteorite crater, western Finland: preliminary results of deep drilling. Tectonophysics 216, 91 - 97.

Reading, H.G., 1986. Facies. In: Reading, H.G. (ed.), Sedimentary Environments and Facies. 4-19.

Reimold, W.U., Barr, J.M., Grieve, R.A.F. \& Durrheim, R.J., 1990. Geochemistry of the melt and country rocks of the Lake St. Martin impact structure, Manitoba, Canada. Geochimica et Cosmochimica Acta 54, 2093 - 2111.

Short, N.M., 1968. Experimental microdeformation of rock materials by shock pressures from laboratoryscale impacts and explosions. In: French, B.M. \& Short, N.M. (ed.) Shock Metamorphism on Natural Materials. Mono Book Corp., Baltimore. 219 - 241.

Selley, R.C., 1970. Ancient sedimentary environments. Chapman and Hall. London. 287 p.

Simonen, A., 1980. The Precambrian in Finland. Geological Survey of Finland, Bulletin 304, 58 pp.

Simonen, A. \& Kouvo, O., 1954. Sandstones in Finland. Bulletin de la Commission Géologique de Finlande $168,57-87$.

Soininen, H. \& Jokinen, T., 1991. SAMPO, a new wide-band electromagnetic system. Technical Programme and Abstracts of Papers, EAEG 53rd Meeting and Technical Exhibition, Florence, Italy, 26 May - 30 May 1991, 366 - 367.

Stöffler, D., 1977. Research drilling Nördlingen 1973: polymict breccias, crater basement, and cratering model of the Ries impact structure. Geologica Bavarica 75, 443 - 458.

Störr, M., Kuvart, M. \& Neuil, J., 1978. Age and Genesis of the Weathering Crust of Bohemian Massif. Schriftenreiche für Geologische Wissenschaften. Heft 11. V. Internationales Symposium - Genese des Kaolins 14-20.9.1975., 265 - 283.

Tynni, R., 1978. Muhoksen muodostuman mikrofossiilitutkimuksen tuloksia. Geologinen tutkimuslaitos, Tutkimusraportti $30.18 \mathrm{pp}$.

Tynni, R. \& Donner, J., 1980. A microfossil and sedimentation study of the Late Precambrian formation of Hailuoto, Finland. Geological Survey of Finland, Bulletin 311, 27 pp.

Tynni, R. \& Uutela, A., 1984. Microfossils from the Precambrian Muhos formation in Western Finland. Geological Survey of Finland, Bulletin 330. 38 pp.

Tynni, R. \& Uutela, A. 1985. Myöhäis-prekambrinen ajoitus Taivalkosken savikivelle mikrofossiilien perusteella. Summary: Late Precambrian shale formation of Taivalkoski in Northern Finland. Geologi 37, 61 65.

Vaasjoki, M, \& Sakko, M., 1988. The evolution of the Raahe - Ladoga zone in Finland: Isotopic contrains. Geological Survey of Finland, Bulletin 343, 7 - 32. 
Veltheim, V., 1969. On the pre-Quaternary geology of the Bothnian bay area and in the Baltic Sea. Bulletin de la Commission Géologique de Finlande 239, 56 pp. Vidal, G. \& Knoll, A.H. 1982. Radiations and extinctions of plankton in the late Proterozoic and early Cambrian. Nature 297, 57 - 60.

Vidal, G. \& Knoll, A.H., 1983. Protozoic plankton.

Geological Society of America, Memoir 161, 265 277.

Volkova, N.A., 1990. Acritarchs and Other Plant Microfossils of the East European Platform. In: Sokolov, B.S. \& Iwanowski, A.B. (eds.), The Vendian System. Vol. 1.Paleontology. Springer-Verlag, Berlin. $155-165$.

Vorma, A., 1971. Pre-Quaternary rocks, Sheet - 3232
- Pieksämäki. Geological Map of Finland, 1:100 000. Geologinen tutkimuslaitos (Geological Survey).

Yankauskas, T.V., Mikhailova, N.S., German, T.N., Sergeyev, V.N., Abduazimova, Z.M., Belova, M.Yu., Burzin, M.B., Veis, A.F., Volkova, N.A., Golovionok, V.K., Grigorijeva, A.Ye., Kirjanov, V.V., Kozlova, Ye.V., Kolosov, P.N., Kraskov, L.N., Krylov, I.N., Luchinina, V.A., Medvedeva, A.M., Oqurtzova, R.N.,Paskiavichene, L.T., Piatiletov, V.G., Rudavskaya, V.A., Sivertzeva, I.A., Stanevich, A.M., Treshchetenkova, A.A., Faizulina, Z.Kh., Chepikova, I.K., Shenfil, V.Yu., Shepeleva, E.D. \& Yaksin, M.S. 1989. Precambrian microfossils of the USSR (in Russian). Akad. Nauk. Institut Geologii i Geohronolgii Dokembrija. Leningrad, 200 pp. 